\title{
Regression Equations for Monthly and Annual Mean and Selected Percentile Streamflows for Ungaged Rivers in Maine
}

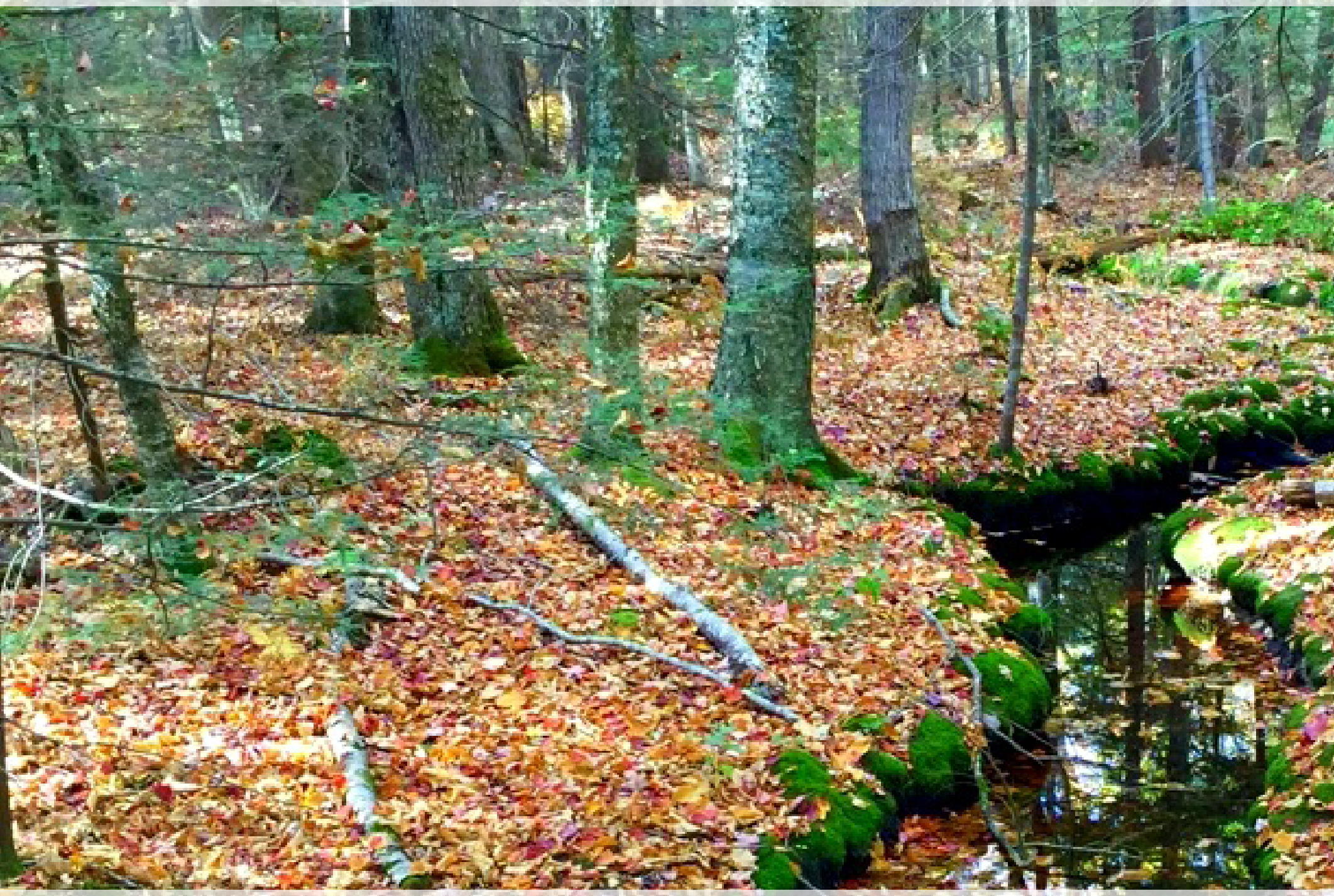

Scientific Investigations Report 2015-5151

Version 1.1, December 21, 2015 
Cover. Unnamed stream at Ferry Beach State Park, Saco, Maine. Photograph courtesy of Melissa Williams of McLean, Virginia. 


\section{Regression Equations for Monthly and Annual Mean and Selected Percentile Streamflows for Ungaged Rivers in Maine}

By Robert W. Dudley

Prepared in cooperation with the Maine Department of Transportation

Scientific Investigations Report 2015-5151

Version 1.1, December 21, 2015 


\title{
U.S. Department of the Interior SALLY JEWELL, Secretary
}

\section{U.S. Geological Survey Suzette M. Kimball, Director}

\author{
U.S. Geological Survey, Reston, Virginia \\ First release: December 2015 \\ Revised: December 21, 2015 (ver. 1.1)
}

\begin{abstract}
For more information on the USGS - the Federal source for science about the Earth, its natural and living resources, natural hazards, and the environment-visit http://www.usgs.gov or call 1-888-ASK-USGS.

For an overview of USGS information products, including maps, imagery, and publications, visit http://www.usgs.gov/pubprod/.
\end{abstract}

\footnotetext{
Any use of trade, firm, or product names is for descriptive purposes only and does not imply endorsement by the U.S. Government.

Although this information product, for the most part, is in the public domain, it also may contain copyrighted materials as noted in the text. Permission to reproduce copyrighted items must be secured from the copyright owner.

Suggested citation:

Dudley, R.W., 2015, Regression equations for monthly and annual mean and selected percentile streamflows for ungaged rivers in Maine (ver. 1.1, December 21, 2015): U.S. Geological Survey Scientific Investigations Report 20155151, 35 p., http://dx.doi.org/10.3133/sir20155151.

ISSN 2328-0328 (online)
} 


\section{Acknowledgments}

The author thanks the Maine Department of Transportation for providing support for this study. Thanks also are given to Luke Sturtevant of the U.S. Geological Survey for geographic information system support and assistance. Reviews by Gardner Bent, Pam Lombard, and Anna Glover of the U.S. Geological Survey resulted in scientific and editorial improvements in this report. 



\section{Contents}

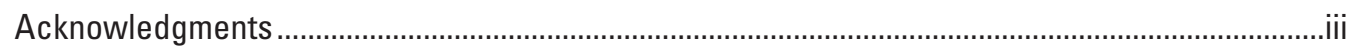

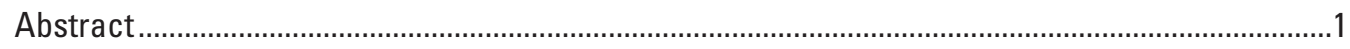

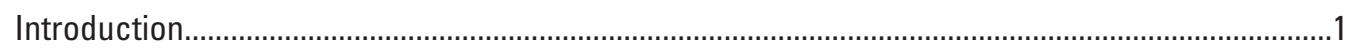

Purpose and Scope ......................................................................................................

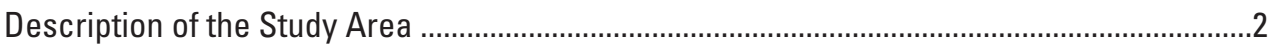

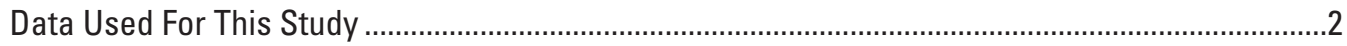

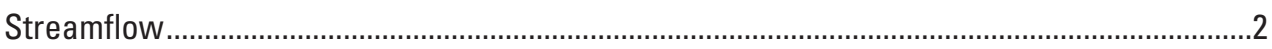

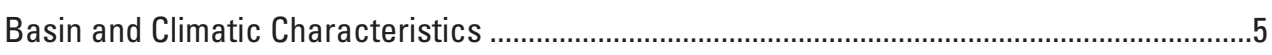

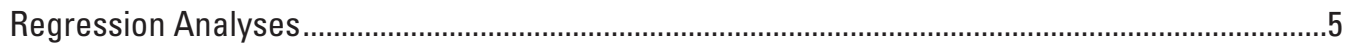

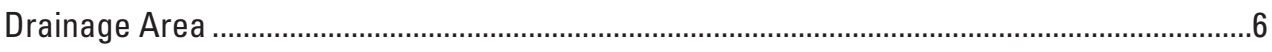

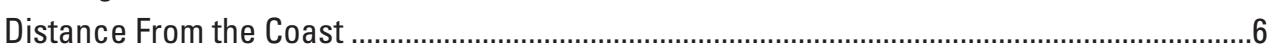

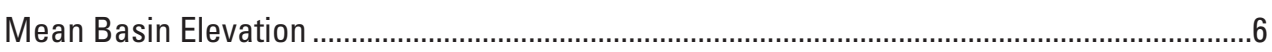

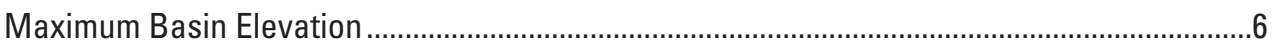

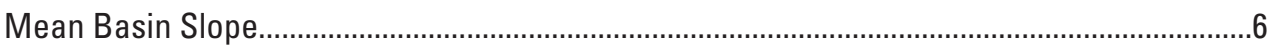

Mean Basin Percent Hydrologic Soil Group A ……….......................................................

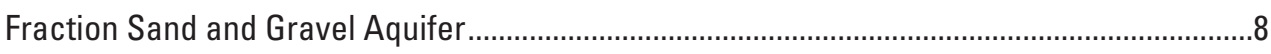

Percent Open Water....................................................................................................

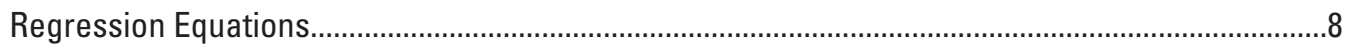

Summary

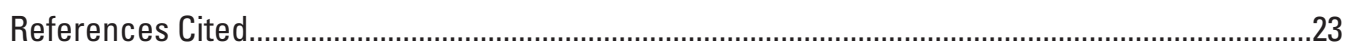

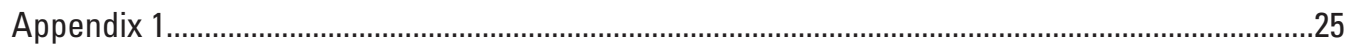

\section{Figures}

1. Map showing locations of U.S. Geological Survey streamgages and basins in Maine and northern New Hampshire used in this study. ..................................................

2. Map showing distribution of hydrologic soil group $A$ in Maine and New Hampshire ......9

3. Map showing distribution of sand and gravel aquifers in Maine and New Hampshire. 10

4. Map showing distribution of land cover classified as open water in the 2006 National Land Cover Dataset (NLCD) in Maine and New Hampshire..

5. Two-dimensional ranges of explanatory variables used in regression equations for estimating annual and July, August, September, and October mean and selected percentile streamflows for ungaged, unregulated streams in rural drainage basins in Maine and northern New Hampshire

6. Two-dimensional range of explanatory variables used in regression equations for estimating January and December mean and selected percentile streamflows for ungaged, unregulated streams in rural drainage basins in Maine and northern New Hampshire

7. Two-dimensional ranges of explanatory variables used in regression equations for estimating February, March, April, May, and June mean and selected percentile streamflows for ungaged, unregulated streams in rural drainage basins in Maine and northern New Hampshire. 
8. Two-dimensional range of explanatory variables used in regression equations for estimating November mean and selected percentile streamflows for ungaged, unregulated streams in rural drainage basins in Maine and northern New Hampshire .....

\section{Tables}

1. Selected U.S. Geological Survey streamgages in Maine and northern New Hampshire

2. Basin characteristics for selected U.S. Geological Survey streamgages in Maine and northern New Hampshire.....

3. Point coordinates defining the Gulf of Maine Line .

4. Regression equations for estimating annual streamflows for ungaged, unregulated streams in rural drainage basins in Maine and northern New Hampshire

5. Regression equations for estimating January streamflows for ungaged, unregulated streams in rural drainage basins in Maine and northern New Hampshire

6. Regression equations for estimating February streamflows for ungaged, unregulated streams in rural drainage basins in Maine and northern New Hampshire

7. Regression equations for estimating March streamflows for ungaged, unregulated streams in rural drainage basins in Maine and northern New Hampshire

8. Regression equations for estimating April streamflows for ungaged, unregulated streams in rural drainage basins in Maine and northern New Hampshire

9. Regression equations for estimating May streamflows for ungaged, unregulated streams in rural drainage basins in Maine and northern New Hampshire

10. Regression equations for estimating June streamflows for ungaged, unregulated streams in rural drainage basins in Maine and northern New Hampshire

11. Regression equations for estimating July streamflows for ungaged, unregulated streams in rural drainage basins in Maine and northern New Hampshire

12. Regression equations for estimating August streamflows for ungaged, unregulated streams in rural drainage basins in Maine and northern New Hampshire

13. Regression equations for estimating September streamflows for ungaged, unregulated streams in rural drainage basins in Maine and northern New Hampshire

14. Regression equations for estimating October streamflows for ungaged, unregulated streams in rural drainage basins in Maine and northern New Hampshire

15. Regression equations for estimating November streamflows for ungaged, unregulated streams in rural drainage basins in Maine and northern New Hampshire

16. Regression equations for estimating December streamflows for ungaged, unregulated streams in rural drainage basins in Maine and northern New Hampshire 


\section{Conversion Factors}

International System of Units to Inch/Pound

\begin{tabular}{lll}
\hline \multicolumn{1}{c}{ Multiply } & \multicolumn{1}{c}{ By } & \multicolumn{1}{c}{ To obtain } \\
\hline millimeter $(\mathrm{mm})$ & Length & \\
meter $(\mathrm{m})$ & 0.03937 & inch (in.) \\
kilometer $(\mathrm{km})$ & 3.281 & foot $(\mathrm{ft})$ \\
\hline & 0.6214 & mile $(\mathrm{mi})$ \\
\hline square kilometer $\left(\mathrm{km}^{2}\right)$ & Area & \\
\hline & 0.3861 & square mile $\left(\mathrm{mi}^{2}\right)$ \\
\hline cubic meter per second $\left(\mathrm{m}^{3} / \mathrm{s}\right)$ & Flow rate & \\
\hline
\end{tabular}

Temperature in degrees Celsius $\left({ }^{\circ} \mathrm{C}\right)$ may be converted to degrees Fahrenheit $\left({ }^{\circ} \mathrm{F}\right)$ as $^{\circ} \mathrm{F}=\left(1.8 \times{ }^{\circ} \mathrm{C}\right)+32$.

\section{Datum}

Vertical coordinate information is referenced to the North American Vertical Datum of 1988 (NAVD 88).

Horizontal coordinate information is referenced to the North American Datum of 1983 (NAD 83).

Elevation, as used in this report, refers to distance above the vertical datum. 


\section{Abbreviations}

$\begin{array}{ll}\text { ASEP } & \text { average standard error of prediction } \\ \text { GAGES II } & \text { Geospatial Attributes of Gages for Evaluating Streamflow version II } \\ \text { GIS } & \text { geographic information system } \\ \text { MDOT } & \text { Maine Department of Transportation } \\ \text { MEGIS } & \text { Maine Office of GIS } \\ \text { NED } & \text { National Elevation Dataset } \\ \text { NRCS } & \text { Natural Resources Conservation Service } \\ \text { NWIS } & \text { National Water Information System } \\ \text { PRESS } & \text { prediction error sum of squares } \\ \text { STATSGO } & \text { State Soil Geographic database } \\ \text { USGS } & \text { U.S. Geological Survey } \\ \text { VIF } & \text { variance inflation factor } \\ \text { WLS } & \text { weighted least squares } \\ \text { WY } & \text { water year }\end{array}$




\title{
Regression Equations for Monthly and Annual Mean and Selected Monthly Percentile Streamflows for Ungaged Rivers in Maine
}

\author{
By Robert W. Dudley
}

\section{Abstract}

In an effort to delineate hydrologic conditions in Maine, the U.S. Geological Survey, in cooperation with the Maine Department of Transportation, used streamflow data to develop dependent variables for 130 regression equations for estimating monthly and annual mean and 1, 5, 10, 25, 50, 75, 90,95 , and 99 percentile streamflows for ungaged, unregulated rivers in Maine. Daily streamflow data from 24 rural unregulated basins with drainage areas between 14.9 and 1,419 square miles in Maine and northern New Hampshire were used in the derivation of the equations. Streamflow data collected from October 1, 1982, through September 30, 2012, were used to derive the dependent variables for this study to represent current [2015] hydrologic conditions in Maine and northern New Hampshire. Weighted least squares regression techniques were used to derive the final coefficients and measures of uncertainty for the regression equations. Eight basin characteristics serve as the explanatory variables: drainage area, distance from the coast, mean and maximum basin elevation, mean basin slope, mean basin percentage of hydrologic soil group A, fraction of sand and gravel aquifers, and percentage of open water.

The largest average errors of prediction are associated with regression equations for the lowest streamflows derived for months during which the lowest streamflows of the year occur (such as the 5 and 1 monthly percentiles for August and September). The regression equations have been derived on the basis of streamflow and basin characteristics data for unregulated, rural drainage basins without substantial streamflow or drainage modifications (for example, diversions and (or) regulation by dams or reservoirs, tile drainage, irrigation, channelization, and impervious paved surfaces), therefore using the equations for regulated or urbanized basins with substantial streamflow or drainage modifications will yield results of unknown error. Input basin characteristics derived using techniques or datasets other than those documented in this report or using values outside the ranges used to develop these regression equations also will yield results of unknown error.

\section{Introduction}

Water- and natural-resources professionals routinely need to be able to estimate various streamflow statistics to manage resources, plan projects, and permit regulated uses of surface waters. For example, quantifying streamflows at a given location on a stream may be necessary for determining adequate dilution of waste load to a stream during low-flow conditions (typical of dry conditions during summer), evaluating a hydraulic structure's conveyance during high-flow conditions (typical of wet conditions during spring snowmelt or during large rain events), and evaluating or planning hydraulic connectivity and fish passage efficacy over a range of seasonal flows ranging from low to high. Although estimation of streamflow statistics at or near locations where streamflow data are routinely collected is straightforward, only a small fraction of all the streams in Maine are gaged.

Regression equations offer a statistical method for estimating streamflows at ungaged locations. The U.S. Geological Survey (USGS) has derived a variety of statewide and regional regression equations for estimating a range of streamflow statistics for ungaged streams in Maine. Hodgkins (1999) documents statewide regression equations for estimating peak flows with probabilities of annual exceedances of $0.2,1,2$, 4, 10, 20, and 50 percent. Dudley (2004) derived statewide equations for estimating monthly and annual mean and median streamflows as well as the 7-day low flow with a 10 percent annual exceedance probability, superseding similar equations derived by Parker (1977). A few regional studies within Maine have produced regression equations for specific months: June and August median streamflows in southern Maine (Lombard, 2010), August median streamflows in eastern coastal Maine (Lombard, 2004), and August median streamflows in eastern Aroostook County (Lombard and others, 2003). In 2012, the USGS began a cooperative investigation with the Maine Department of Transportation (MDOT) to derive statewide regression equations that can be used to estimate monthly and annual mean and 1, 5, 10, 25, 50, 75, 90, 95, and 99 percentile streamflows for ungaged rivers in Maine. 


\section{Purpose and Scope}

This report documents regression equations developed for estimating monthly and annual mean and 1, 5, 10, 25, 50, $75,90,95$, and 99 percentile streamflows for ungaged, unregulated rivers in Maine and northern New Hampshire along with the data and methods used to derive them. Statistics derived from streamflow data from 24 USGS streamgages on unregulated, rural rivers in Maine and northern New Hampshire were used as the dependent variables in the equations. Data describing various basin and climate characteristics, such as geology, land cover, land use, precipitation, and temperature, derived using geographic information systems (GIS) were used as explanatory variables in the equations. The regression equations presented in this report can be used to estimate streamflows for unregulated, rural basins in Maine and supersede those derived by Dudley (2004) because of the updated streamflow and basin characteristics data used.

\section{Description of the Study Area}

The State of Maine (fig. 1), in the northeastern United States, has a land area of 79,883 square kilometers $\left(\mathrm{km}^{2} ; 30,843\right.$ square miles $\left.\left[\mathrm{mi}^{2}\right]\right)$ with a population of 1.33 million people (U.S. Census Bureau, 2012). Maine is largely rural and forested with rolling topography of moderate to low relief throughout the State except for the high relief of the Appalachian Mountain Range in west-central Maine. Land elevation ranges from sea level $(0$ meters $[\mathrm{m}] ; 0$ feet $[\mathrm{ft}])$ at the Atlantic coast (Gulf of Maine) to 1,606 $\mathrm{m}(5,268 \mathrm{ft}$ ) at the peak of Mount Katahdin (U.S. Geological Survey, 2001). The physiographic characteristics of west-central Maine extend into northernmost New Hampshire.

Basin characteristics and streamflow data from 24 streamgages on rural, unregulated basins in Maine and northern New Hampshire (fig. 1) were used to derive the regression equations for estimating selected streamflow statistics. The study basins have no substantial streamflow or drainage modifications (that is, diversions and (or) regulation by dams or reservoirs, tile drainage, irrigation, channelization, and impervious paved surfaces large enough to affect the computation of monthly statistics). The study basins range in size from 38.6 to $3,675 \mathrm{~km}^{2}$ (14.9 to $1,419 \mathrm{mi}^{2}$ ), with mean basin elevations ranging from $73 \mathrm{~m}(240 \mathrm{ft})$ at the coast in southern Maine to $646 \mathrm{~m}(2,120 \mathrm{ft})$ in mountainous northern New Hampshire (Gesch and others, 2009; U.S. Geological Survey, 2014a).

The study basins are mostly forested, with deciduous or evergreen growth or a mix thereof (including shrub growth), covering from 67.6 to 99.2 percent (mean of 85.2 percent) of the study basin areas. Open water and wetlands compose 0.4 to 18.6 percent (mean of 8.3 percent) of the study basin areas. Land cover in the basins also includes developed land (residential housing, commercial and industrial development, and transportation; where impervious surfaces account for 20 to 100 percent of total cover) ranging from 0 to 3.7 percent (mean of 0.7 percent) and pasture and cultivated crop areas ranging from 0 to 11.6 percent (mean of 2.4 percent; Fry and others, 2011). Although the rural character of Maine has changed little since the beginning of the 20th century, the greatest changes in land use in Maine has been the replacement of agriculture and pasture lands by forest. The overall forest cover in the State is estimated to have been at its lowest around 1900 at about 70 percent. Forest cover increased to about 90 percent by 1995 (Irland, 1998).

Maine has a temperate climate with mild summers and cold winters. Climatological averages computed for the 30-year period from 1981 to 2010 indicate a mean annual air temperature for Maine of 5.8 degrees Celsius $\left({ }^{\circ} \mathrm{C}\right.$; 42.5 degrees Fahrenheit $\left.\left[{ }^{\circ} \mathrm{F}\right]\right)$. Mean annual air temperature ranged from $2.9^{\circ} \mathrm{C}\left(37.3^{\circ} \mathrm{F}\right)$ at Allagash to $8.8^{\circ} \mathrm{C}\left(47.8^{\circ} \mathrm{F}\right)$ at Sanford. For the same period, the statewide mean minimum air temperature was $0.1^{\circ} \mathrm{C}\left(32.1^{\circ} \mathrm{F}\right)$ and the mean maximum was $11.6^{\circ} \mathrm{C}\left(52.9^{\circ} \mathrm{F}\right)$. Precipitation in Maine is fairly evenly distributed throughout the year with a mean annual of 1,153 millimeters ( $\mathrm{mm}$; 45.4 inches [in.]) for the 30-year period from 1981 to 2010 , ranging from $853 \mathrm{~mm}$ (33.6 in.) at Frenchville to $1,440 \mathrm{~mm}$ (56.7 in.) at Acadia National Park (National Climatic Data Center, 2015).

\section{Data Used For This Study}

\section{Streamflow}

Daily streamflow data collected at USGS streamgages (Rantz and others, 1982) on 24 rural, unregulated river basins in Maine and northern New Hampshire (fig. 1) were used to compute the statistics to serve as dependent variables for the regression equations developed. Candidate streamgages for this study needed to be located in Maine or in New Hampshire within $25 \mathrm{mi}$ of the Maine border, in predominantly rural basins, and have more than 10 years of streamflow data substantially unaffected by diversions and (or) regulation by dams or reservoirs (table 1). The data were daily values derived and published from continuously collected data (typically in 15-minute intervals). Daily streamflow data were retrieved from the National Water Information System (NWIS; U.S. Geological Survey, 2014c) for the streamgages meeting the study criteria. Only a 6-day period of irregular low-flow regulation during September 20-25, 1985, for the Narraguagus River at Cherryfield, Maine (01022500) streamgage was censored from use in this study.

Recent studies of climate variability and its effect on hydrology in Maine and New England have documented various trends over time. Many changes have been observed in the winter and spring seasons, during which high snowmelt-related streamflows have trended to earlier dates during the course of the 20th century (Dudley and Hodgkins, 2002; Hodgkins and others, 2003; Hodgkins and Dudley, 


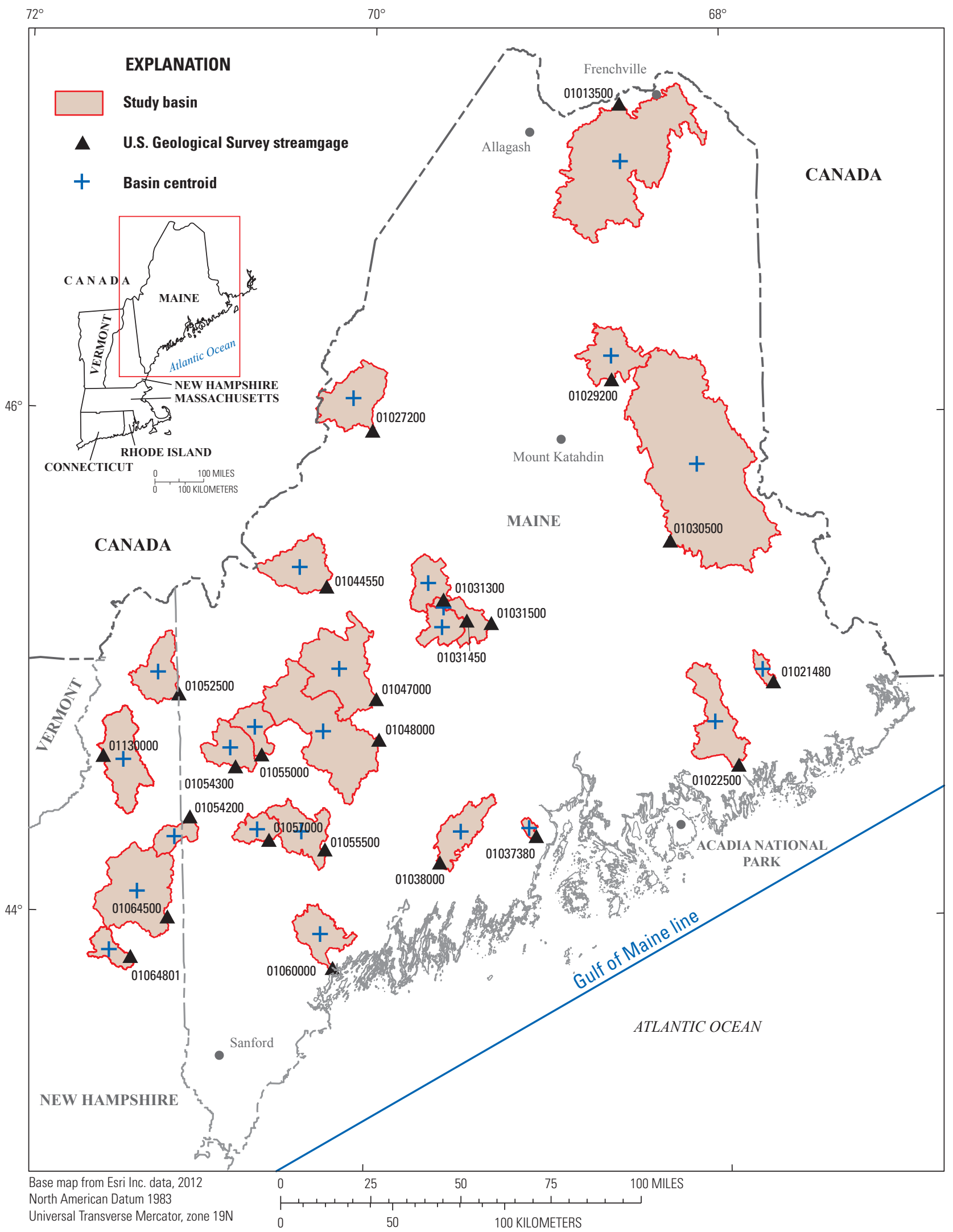

Figure 1. Locations of U.S. Geological Survey streamgages and basins in Maine and northern New Hampshire used in this study. The Gulf of Maine line is a line in the Gulf of Maine defined by end points $71 \mathrm{~W}, 42.75 \mathrm{~N}$ and $65.5 \mathrm{~W}, 45 \mathrm{~N}$, referenced to the North American Datum of 1983 for measuring the distance from the coast for each of the basins. 
Table 1. Selected U.S. Geological Survey streamgages in Maine and northern New Hampshire.

$\left[\mathrm{mi}^{2}\right.$, square mile; WY, water year which begins October 1 and ends September 30 and is designated by the calendar year in which it ends]

\begin{tabular}{|c|c|c|c|c|}
\hline \multicolumn{2}{|r|}{ U.S. Geological Survey streamgage } & \multirow{2}{*}{$\begin{array}{l}\text { Drainage area } \\
\qquad\left(\mathrm{mi}^{2}\right)\end{array}$} & \multirow{2}{*}{$\begin{array}{l}\text { Period of record used in } \\
\text { this study } \\
\text { (WY) }\end{array}$} & \multirow{2}{*}{$\begin{array}{c}\text { Number of } \\
\text { complete WY }\end{array}$} \\
\hline Number & Name & & & \\
\hline 01013500 & Fish River near Fort Kent, Maine & 866 & $1983-2012$ & 30 \\
\hline 01021480 & Old Stream near Wesley, Maine & 29.8 & $1998-2012$ & 14 \\
\hline 01022500 & Narraguagus River at Cherryfield, Maine & 228 & $1983-2012$ & 29 \\
\hline 01027200 & North Branch Penobscot River near Pittston Farm, Maine & 223 & $2001-2012$ & 11 \\
\hline 01029200 & Seboeis River near Shin Pond, Maine & 173 & $1998-2012$ & 14 \\
\hline 01030500 & Mattawamkeag River near Mattawamkeag, Maine & 1,419 & $1983-2012$ & 30 \\
\hline 01031300 & Piscataquis River at Blanchard, Maine & 117 & $1997-2012$ & 16 \\
\hline 01031450 & Kingsbury Stream at Abbot Village, Maine & 95.1 & $1997-2012$ & 15 \\
\hline 01031500 & Piscataquis River near Dover-Foxcroft, Maine & 297 & 1983-2012 & 30 \\
\hline 01037380 & Ducktrap River near Lincolnville, Maine & 14.9 & $1998-2012$ & 14 \\
\hline 01038000 & Sheepscot River at North Whitefield, Maine & 145 & $1983-2012$ & 30 \\
\hline 01044550 & Spencer Stream near Grand Falls, Maine & 194 & 1999-2012 & 13 \\
\hline 01047000 & Carrabassett River near North Anson, Maine & 352 & $1983-2012$ & 30 \\
\hline 01048000 & Sandy River near Mercer, Maine & 516 & $1987-2012$ & 25 \\
\hline 01052500 & Diamond River near Wentworth Location, New Hampshire & 153 & 1983-2012 & 30 \\
\hline 01054200 & Wild River at Gilead, Maine & 69.9 & 1983-2012 & 30 \\
\hline 01054300 & Ellis River at South Andover, Maine & 130 & $2001-2012$ & 11 \\
\hline 01055000 & Swift River near Roxbury, Maine & 96.8 & $1983-2012$ & 30 \\
\hline 01055500 & Nezinscot River at Turner Center, Maine & 168 & 1983-1996, 2001-2012 & 25 \\
\hline 01057000 & Little Androscoggin River near South Paris, Maine & 73.9 & $1983-2012$ & 30 \\
\hline 01060000 & Royal River at Yarmouth, Maine & 141 & 1983-2004 & 21 \\
\hline 01064500 & Saco River near Conway, New Hampshire & 385 & $1983-2012$ & 30 \\
\hline 01064801 & Bearcamp River at South Tamworth, New Hampshire & 67.0 & $1993-2012$ & 19 \\
\hline 01130000 & Upper Ammonoosuc River near Groveton, New Hampshire & 231 & 1983-2004, 2009-2012 & 25 \\
\hline
\end{tabular}

2006b). These winter and spring streamflow trends have been accompanied by earlier lake ice-out dates (Hodgkins, 2013), decreases in late-winter snowpack depth or increases in snowpack density (Hodgkins and Dudley, 2006a), and a decreased ratio of snowfall to total precipitation at sites in northern New England (Huntington and others, 2004).

Precipitation in New England has increased across all seasons (Karl and Knight, 1998; Douglas and Fairbank, 2011; Hodgkins and Dudley, 2011). Annual low streamflows at several streamgages in northern New England have increased during the 20th century (Hodgkins and Dudley, 2005) and annual peak flows have increased during the past 50 to 100 years at several streamgages across New England (Hodgkins and Dudley, 2005; Collins, 2009; Hodgkins, 2010; Armstrong and others, 2012).

The regression equations by Dudley (2004) integrated all historical streamflow and precipitation data available at the time. However, given the evidence of hydrologic trends, future investigations of this kind might benefit from being done at regular intervals using a moving temporal window of contemporary data or considering methods for incorporating these large-scale hydrologic trends into the statistical models. Therefore, to best represent contemporary hydrologic conditions in Maine, streamflow data collected during the 30-year period from October 1, 1982, through September 30, 2012 (water years ${ }^{1}$ 1983-2012), are used to derive the dependent variables for the study in this report (table 1).

Monthly and annual streamflow.-Mean annual streamflow was computed as the mean of all available daily mean streamflow data for the period of record during water years 1983 to 2012 for each station (appendix 1). Mean monthly streamflows were computed as the mean of all daily mean streamflow values parsed by month. The $1,5,10,25,50,75,90$, 95 , and 99 monthly and annual percentile streamflows were

\footnotetext{
${ }^{1}$ The water year begins October 1 and ends September 30 and is designated by the calendar year in which it ends.
} 
computed in the manner defined by Helsel and Hirsh (2002); for example, they define the 75th percentile, as "a value which exceeds no more than 75 percent of the data and is exceeded by no more than 25 percent of the data." The computations were done using the quantile function (type=2) in the $R$ programming language. Annual percentiles were computed on the basis of all available daily mean streamflow data for the period of record during water years 1983 to 2012 for each station (appendix 1), and monthly percentiles were computed on the basis of the same daily mean streamflow values parsed by month.

\section{Basin and Climatic Characteristics}

For the study detailed in this report, 68 GIS-derived basin characteristics were tested to serve as explanatory variables for the dependent variables of monthly and annual mean and $1,5,10,25,50,75,90,95$, and 99 percentile streamflows. Most of the basin characteristics were retrieved from the Geospatial Attributes of Gages for Evaluating Streamflow version II (GAGES II) dataset (Falcone, 2011) — an updated version of the original Geospatial Attributes of Gages for Evaluating Streamflow dataset published in 2010 (Falcone and others, 2010). The GAGES II dataset includes several hundred watershed characteristics derived from national data sources, including environmental features and anthropogenic influences for more than 9,000 streamgages maintained by the USGS. The dataset also includes comments pertaining to hydrologic modifications published in USGS annual data reports (U.S. Geological Survey, 2014b).

The 68 basin characteristics comprise the following parameters (and variations thereof): drainage area; latitude and longitude; land surface elevation, shape, aspect, and slope; precipitation; air temperature; days of first and last freeze; snow percent of total precipitation; ratio of base flow to total streamflow; various land-cover classifications from the 2006 National Land Cover Dataset (NLCD; Fry and others, 2011); population density; hydrologic soil group types; area of sand and gravel aquifers; and distance from the coast. These candidate explanatory variables included the five explanatory variables derived by Dudley (2004) for estimating mean monthly, mean annual, and 7-day, 10-year low-flow frequency (7Q10) streamflows: drainage area, area of sand and gravel aquifers, distance from the coast, mean annual precipitation, and mean winter precipitation. Distance from the coast and area of sand and gravel aquifers are not available in the GAGES II dataset and were computed by using GIS; details describing the computation of these basin characteristics is provided in the "Final Explanatory Variables" section.

\section{Regression Analyses}

Ordinary least squares (OLS) regression techniques (Helsel and Hirsch, 2002) of all possible subsets of 68 explanatory variables for each of 130 dependent variables were used to select the explanatory variables that would appear in the final regression equations. For the exploratory OLS regression analyses, all subset regressions were evaluated on the basis of adjusted coefficient of determination $\left(R^{2}\right)$ values and significance of explanatory variables. In general, explanatory variables needed to have statistically significant explanatory power ( $p$-values less than 0.01 ) for several percentile regressions in order to be retained in any model set. In most cases, explanatory variables rarely exhibited statistical significance over the entire range of percentiles, from low to high streamflows, for any given monthly or annual equation set with the exception of drainage area. Explanatory variables other than drainage area often had high statistical significance at either mid-to-high streamflows or mid-to-low streamflows and decreased in significance for the other equations; such variables were nevertheless retained in model sets in the interest of coherence. In the instance of three-variable models, the two explanatory variables other than drainage area often provided complementary statistical significance but were not always both significant for any given percentile model.

For the monthly and annual 1, 5, 10, 25, 50, 75, 90, 95, and 99 percentile streamflows, emphasis was placed on developing a coherent set of equations in which each monthly or annual set of regression equations uses the same set of explanatory variables; only the coefficients vary for each percentile equation. This approach of building coherent monthly and annual regression equation sets reduced the possibility of discontinuities in the percentile estimates (for example, equations that yield a 5 percentile streamflow estimate that is greater than the 10 percentile streamflow estimate).

A variety of regression diagnostics was used to evaluate the capacity of the explanatory variables to explain the variability of the dependent variables and the overall robustness of the derived regression equations. The Cook's D statistic (Helsel and Hirsch, 2002) was used to investigate any problems with leverage influence on the regression equations. Cook's D indicated that basins with small drainage areas (of approximately $26 \mathrm{~km}^{2}\left[10 \mathrm{mi}^{2}\right]$ or less) and (or) mountainous character exerted high leverage; for this reason, 5 candidate streamgage study basins ( 2 in Maine and 3 in New Hampshire) were culled from an original set of 29 streamgages, reducing the final number of streamgage study basins to 24 . Residual plots against predicted values, and partial residuals plots, were used to check for linearity, constant variance, normality, and the presence of outliers. Residuals were plotted and correlated against latitude and longitude to check for geographic bias. All correlation values were less than \pm 0.60 and no monthly or annual model sets indicated any systematic geographic bias. Residuals from 4 of 130 models indicated (strong, $p<0.01$ ) positive correlation with latitude: the May 90, 95 and 99 percentile models and the July 50th percentile model. Residuals from 2 models indicated (strong, $p<0.01$ ) positive correlation with longitude: the December 50 and 75 percentile models. Multicollinearity among the explanatory variables was measured using the variance inflation factor (VIF). The 
final explanatory variables (described in the "Final Explanatory Variables" section) had VIF values of 1.87 or lower, indicating no problems with multicollinearity.

Weighted least squares (WLS) regression techniques were used to derive the final coefficients and measures of uncertainty for the regression equations. Where OLS simply minimizes the squares of the residuals, WLS regression techniques minimize the squares of weighted residuals. The weight factors are determined such that observations with greater variance have less of an influence on the derivation of the regression model. A common application of this is to derive the weights as a function of record length base on the assumption that longer records will have lower variance (are more reliable) than for stations with less data (Helsel and Hirsch, 2002). Weights used in the study detailed in this report were computed as a function of record length, that is, the number of complete water years of record from water years 1983 to 2012 divided by the mean record length ( 23 years) for all the streamgages used in the analysis; the sum of the weights is therefore equal to the number of streamgages used.

Final explanatory variables. - Eight basin characteristics were identified from the initial set of the 68 to serve as explanatory variables for estimating monthly and annual mean and 1 , $5,10,25,50,75,90,95$, and 99 percentile streamflows. The eight basin characteristics are drainage area, distance from the coast, mean and maximum basin elevation, mean basin slope, mean basin percentage of hydrologic soil group $\mathrm{A}$, fraction of sand and gravel aquifers, and percentage of open water (lakes and ponds; table 2). These basin characteristics were recomputed in GIS to check the GAGES II values; the newly derived values were used in the derivation of the final WLS regression equations.

\section{Drainage Area}

The drainage area, in square miles, of each study basin was computed in GIS by measuring the horizontal planar area enclosed by the topographic divide (drainage-basin boundary) inside which surface runoff drains by gravity to a common outlet point (point of interest). The drainage basin boundary was delineated using the National Elevation Dataset (NED) for Maine and northern New Hampshire derived from a $10-\mathrm{m}(1 / 3$ arc-second) resolution digital elevation model (DEM; Gesch and others, 2009; U.S. Geological Survey, 2014a). The 24 streamgage basin drainage areas range from $14.9 \mathrm{mi}^{2}$ (38.6 km²; Ducktrap River near Lincolnville, Maine [01037380] streamgage) to $1,419 \mathrm{mi}^{2}\left(3,675 \mathrm{~km}^{2}\right.$; Mattawamkeag River near Mattawamkeag, Maine [01030500] streamgage), with a mean of $258 \mathrm{mi}^{2}\left(668 \mathrm{~km}^{2}\right.$; fig. 1; tables 1 and 2).

\section{Distance From the Coast}

Distance from the coast is an explanatory variable introduced by Dudley (2004) in regression equations for estimating
January, February, March, and May mean and median streamflows. Distance from the coast is the distance, in miles, measured as the shortest distance from the drainage basin centroid to a line in the Gulf of Maine (GOM line) defined by end points $71 \mathrm{~W}, 42.75 \mathrm{~N}$ and $65.5 \mathrm{~W}, 45 \mathrm{~N}$, referenced to the North American Datum of 1983 (NAD 83; Dudley, 2004). The shortest line of measure between a basin centroid point and the GOM line is a perpendicular intersector of the GOM line. For this study, all distance measurements were made in GIS using NAD 83, Universal Transverse Mercator zone 19 coordinate system (table 3). Distances from the GOM line to the centroid of streamgage drainage basins used in this study range from 46.6 miles (mi; 75 kilometers [km]; Narraguagus River at Cherryfield, Maine [01022500] streamgage) to $193 \mathrm{mi}$ (310.6 km; Fish River near Fort Kent, Maine [01013500] streamgage), with a mean of $102 \mathrm{mi}(164.2 \mathrm{~km}$; table 2).

\section{Mean Basin Elevation}

Mean basin elevation, in thousands of meters, was computed in GIS by arithmetically averaging all 10-m NED grid point elevations, in meters, within the drainage basin boundaries and dividing the mean by 1,000 . The mean basin elevation was computed in meters because it is the native vertical unit in the NED. Mean elevations of streamgage drainage basins used in this study range from $73 \mathrm{~m} \mathrm{(239.5} \mathrm{ft;} \mathrm{Royal} \mathrm{River} \mathrm{at} \mathrm{Yar-}$ mouth, Maine streamgage [01060000]) to $646 \mathrm{~m}(2,119.4 \mathrm{ft}$; Diamond River near Wentworth Location, NH streamgage [01052500]), with a mean of $339 \mathrm{~m}$ (1,112.2 ft; table 2).

\section{Maximum Basin Elevation}

Maximum basin elevation, in thousands of meters, was computed in GIS by identifying the maximum 10-m NED grid point elevation, in meters, within the drainage basin boundaries (typically at the basin boundary), and dividing it by 1,000 . The maximum basin elevation is computed in meters because it is the native vertical unit in the NED. Maximum elevations of streamgage drainage basins used in this study range from 193 m (633.2 ft; Royal River at Yarmouth, Maine [01060000] streamgage) to $1,916 \mathrm{~m}$ (6,286 ft; Saco River near Conway, NH [01064500] streamgage), with a mean of $860 \mathrm{~m}$ $(2,821.5 \mathrm{ft}$; table 2$)$.

\section{Mean Basin Slope}

Mean basin slope, in percent, was computed in GIS by arithmetically averaging all $10-\mathrm{m}$ slope grid points (steepest gradient identified between a cell and its neighboring cells derived from the 10-m NED) within the drainage basin boundaries. The slope grid was computed as the change in elevation between grid points divided by the distance between grid points and multiplied by 100 to obtain units in percent. Mean basin slopes of streamgage drainage basins used in this study 


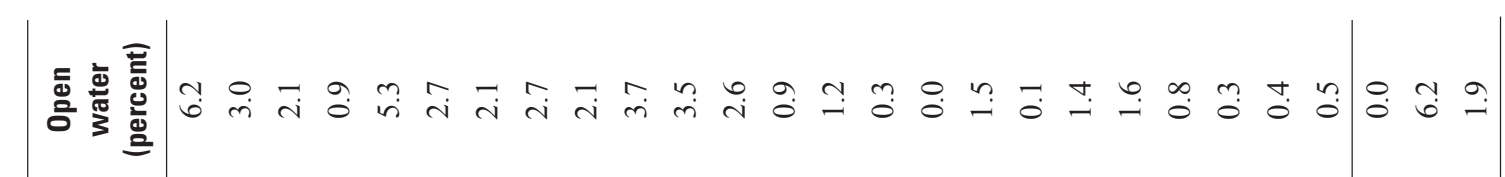

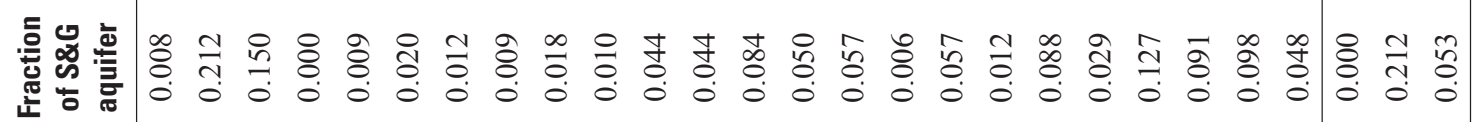

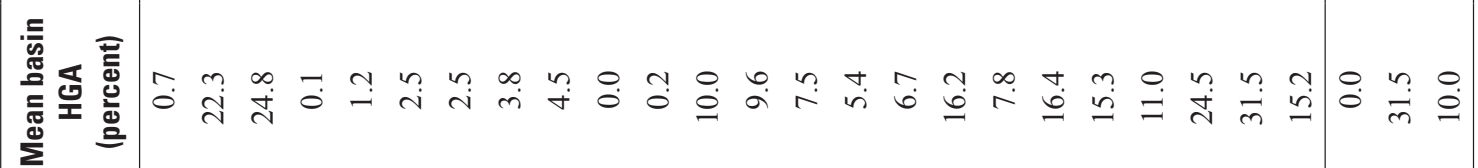

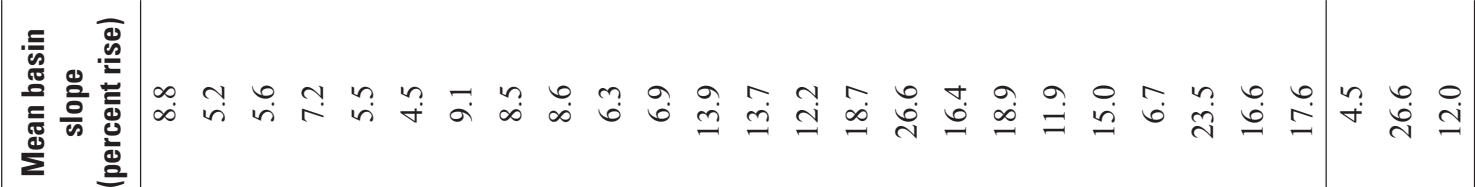

$$
\text { 离 }
$$

$$
\text { ฏे }
$$

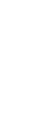

(1)


Table 3. Point coordinates defining the Gulf of Maine Line.

[Point coordinates are in meters, referenced to Universal Transverse Mercator zone 19 datum (fig. 1)]

\begin{tabular}{lcc}
\hline & X coordinate & Y coordinate \\
\hline Point A & 336321.28 & 4734992.89 \\
Point B & 775853.75 & 4988911.83 \\
\hline
\end{tabular}

range from 4.5 percent (Mattawamkeag River near Mattawamkeag, Maine [01030500] streamgage) to 26.6 percent (Wild River at Gilead, Maine [01054200] streamgage), with a mean of 12 percent (table 2).

\section{Mean Basin Percent Hydrologic Soil Group A}

Wolock (1997) aggregated data from the national Natural Resources Conservation Service's (NRCS) State Soil Geographic (STATSGO) database (U.S. Department of Agriculture, 1994) to compute 1-km (0.6-mi) grids of percentages of each hydrologic soil type (A, B, C, and D; U.S. Department of Agriculture, 1986). The gridded datasets of hydrologic soil types have a percentage of each soil type assigned to each grid. The percentages were computed as averages of multiple soil components and layers, weighted on the basis of soil layer thickness and component area quantified in the STATSGO database. Soils classified as hydrologic group A (HGA; fig. 2) are well drained with high infiltration rates (minimum infiltration rate of 8 to 12 millimeters per hour $[\mathrm{mm} / \mathrm{h}]$ or 0.3 to 0.5 inches per hour $[\mathrm{in} / \mathrm{h}]$ ) and high rates of water transmission (greater than $7.6 \mathrm{~mm} / \mathrm{h}$ or $0.3 \mathrm{in} / \mathrm{h}$; Dunne and Leopold, 1978; U.S. Department of Agriculture, 1986). For use in this report, mean basin percent HGA was computed in GIS by arithmetically averaging all 1-km (0.6-mi) HGA grid points within the drainage basin boundaries. The mean basin percentages of soils classified HGA for streamgage drainage basins used in this study range from 0 percent (Ducktrap River near Lincolnville, Maine [01037380] streamgage) to 31.5 percent (Bearcamp River at South Tamworth, NH [01064801] streamgage), with a mean of 10 percent (table 2).

\section{Fraction Sand and Gravel Aquifer}

The Maine Office of GIS (MEGIS) serves a GIS dataset comprising the polygonal boundaries of significant aquifers as delineated by the Maine Geological Survey at a 1:24,000 scale throughout the State of Maine (Maine Office of GIS, 2015). Significant aquifers are sand and gravel glacial deposits having the potential to yield 38 liters per minute (L/min; 10 gallons per minute [gal/min]) or more to a properly constructed well. The aquifers are differentiated by yield in the GIS dataset, denoted by the stored value in the attribute ATYPE. A high-yield aquifer with an estimated yield greater than $189 \mathrm{~L} / \mathrm{min}(50 \mathrm{gal} / \mathrm{min})$ is denoted ATYPE $=1$, and an aquifer with an estimated yield of 38 to $189 \mathrm{~L} / \mathrm{min}$ (10 to $50 \mathrm{gal} / \mathrm{min}$ ) is denoted ATYPE $=2$.

The University of New Hampshire's Geographically Referenced Analysis and Information Transfer (NH GRANIT) Web site, a GIS clearinghouse for the State of New Hampshire, serves a GIS dataset comprising the polygonal boundaries of stratified drift aquifers as delineated by the USGS and the New Hampshire Department of Environmental Services, Water Resources Division (New Hampshire Geographically Referenced Analysis and Information Transfer, 2014). For the purposes of this report, the stratified drift aquifers mapped in northern New Hampshire are considered to be comparable to the significant sand and gravel aquifers mapped in Maine.

The fraction of sand and gravel aquifer was computed as the sum of polygon areas of the mapped sand and gravel aquifers for Maine (ATYPE $=1$ and 2; fig. 3) and (or) the stratified drift aquifers in northern New Hampshire divided by the total basin drainage area. Fractions of sand and gravel aquifer in streamgage drainage basins used in this report range from 0 (North Branch Penobscot River nr Pittston Farm, ME [01027200] streamgage) to 0.212 (Old Stream near Wesley, Maine [01021480] streamgage), with a mean of 0.053 (table 2).

\section{Percent Open Water}

The 2006 NLCD (Multi-Resolution Land Characteristics Consortium, 2014) is a GIS 30-m (98.4-ft) gridded dataset for the conterminous United States where each grid is assigned a single value from 16 possible classes of land cover classification (Fry and others, 2011). Land cover class code 11 is designated open water and is defined as areas of open water, generally with less than 25 percent cover of vegetation or soil — such as lakes and ponds. Percent open water was computed as the sum of the area of all $30-\mathrm{m}$ (98.4-ft) grids designated with land-classification code 11 divided by the total basin drainage area and multiplied by 100 . Percentages of NLCD-classified open water in streamgage drainage basins used in this study (fig. 4) range from 0 percent (Wild River at Gilead, Maine [01054200] streamgage) to 6.2 percent (Fish River near Fort Kent, Maine [01013500] streamgage), with a mean of 1.9 percent (table 2).

\section{Regression Equations}

Regression equations for estimating monthly and annual mean and $1,5,10,25,50,75,90,95$, and 99 percentile streamflows for ungaged rivers in Maine are presented in tables 4 through 16. Drainage area is a highly significant explanatory variable (basin characteristic) for all percentile streamflows and for all monthly and annual mean streamflows; larger drainage basins contribute greater streamflows.

Mean basin elevation is a significant explanatory variable for nearly all percentile streamflows for the annual period and 


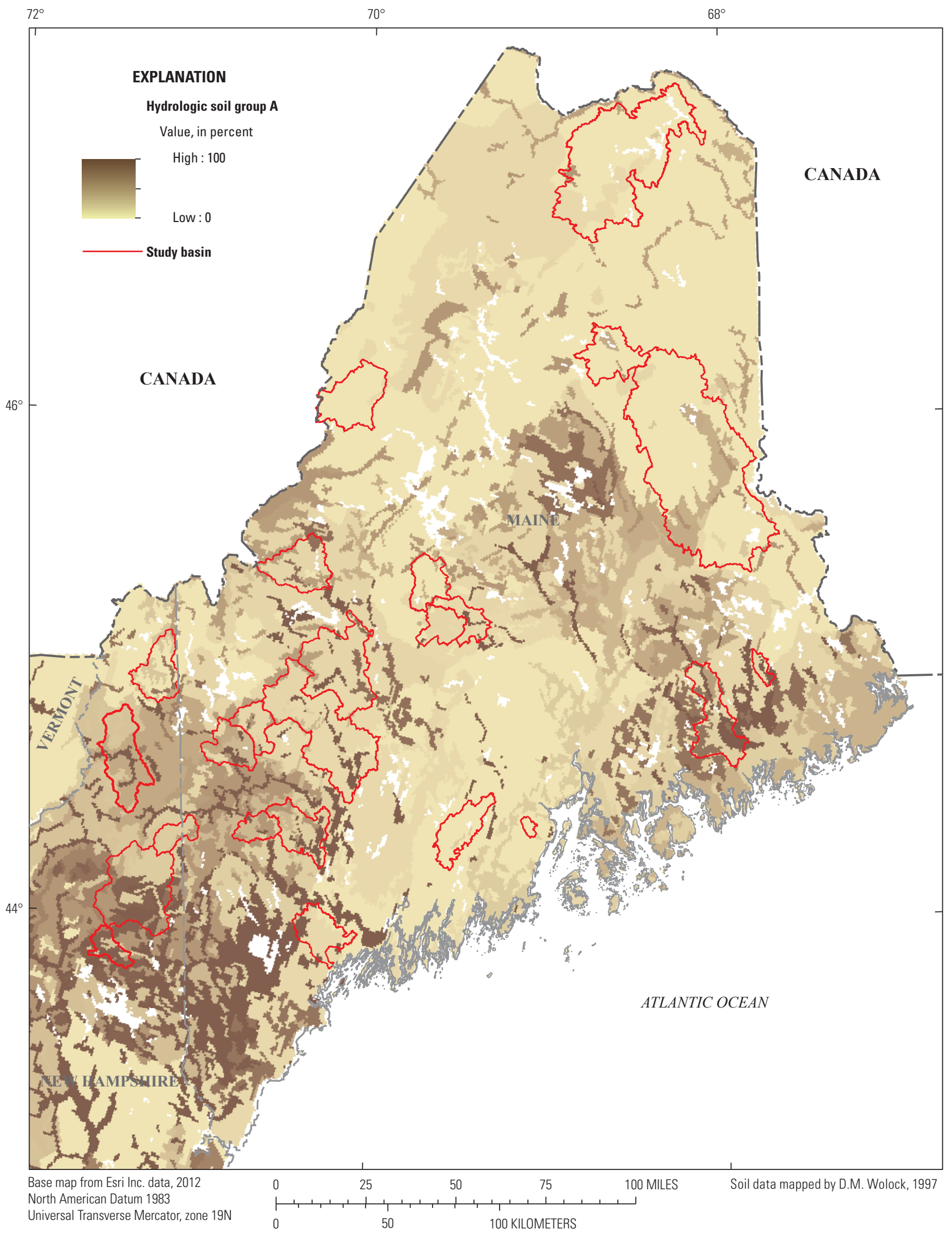

Figure 2. Distribution of hydrologic soil group A in Maine and New Hampshire. 


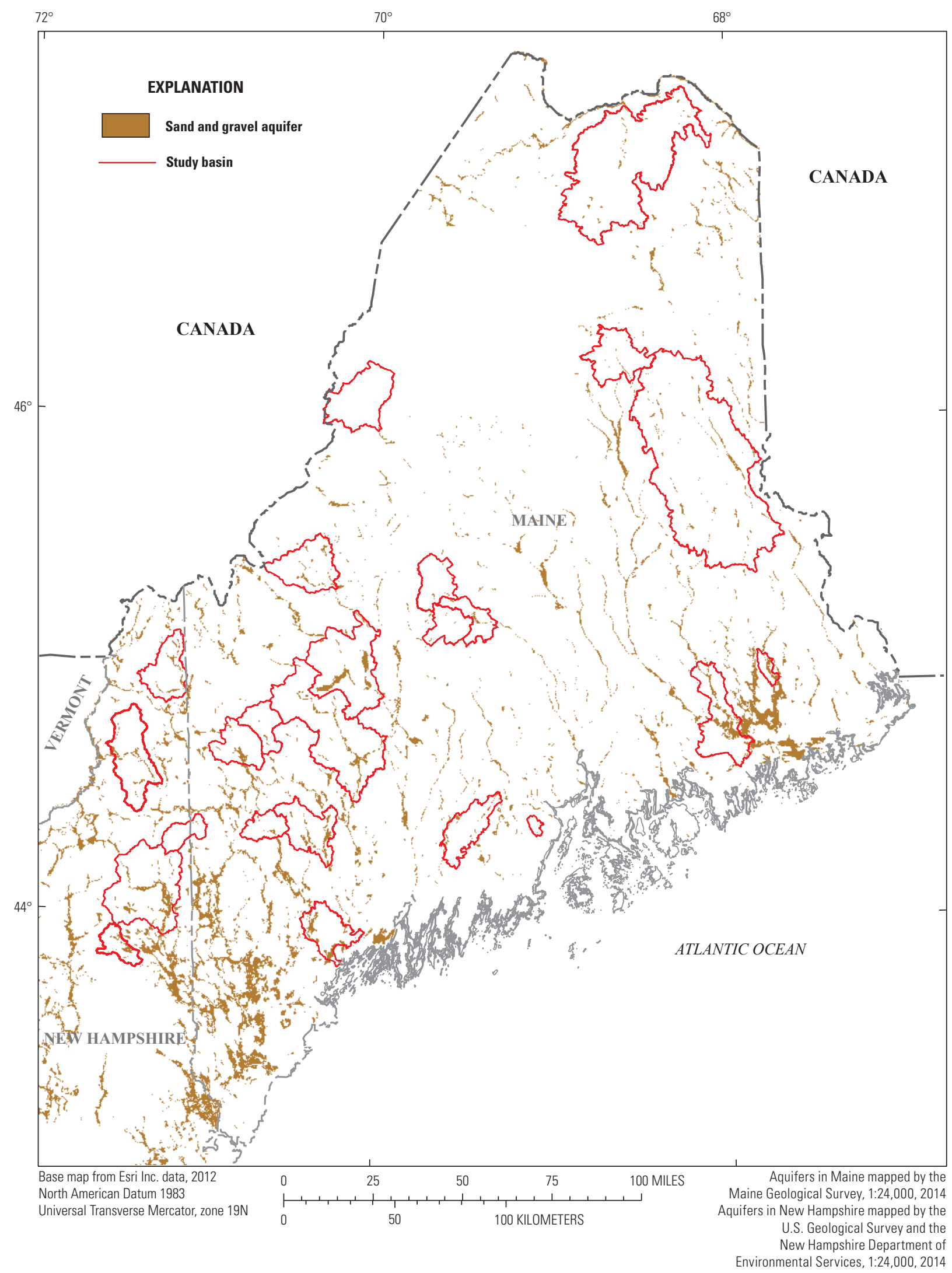

Figure 3. Distribution of sand and gravel aquifers in Maine and New Hampshire. Maine aquifers from Maine Office of GIS (2015) and New Hampshire aquifers from New Hampshire Geographically Referenced Analysis and Information Transfer (2015). 


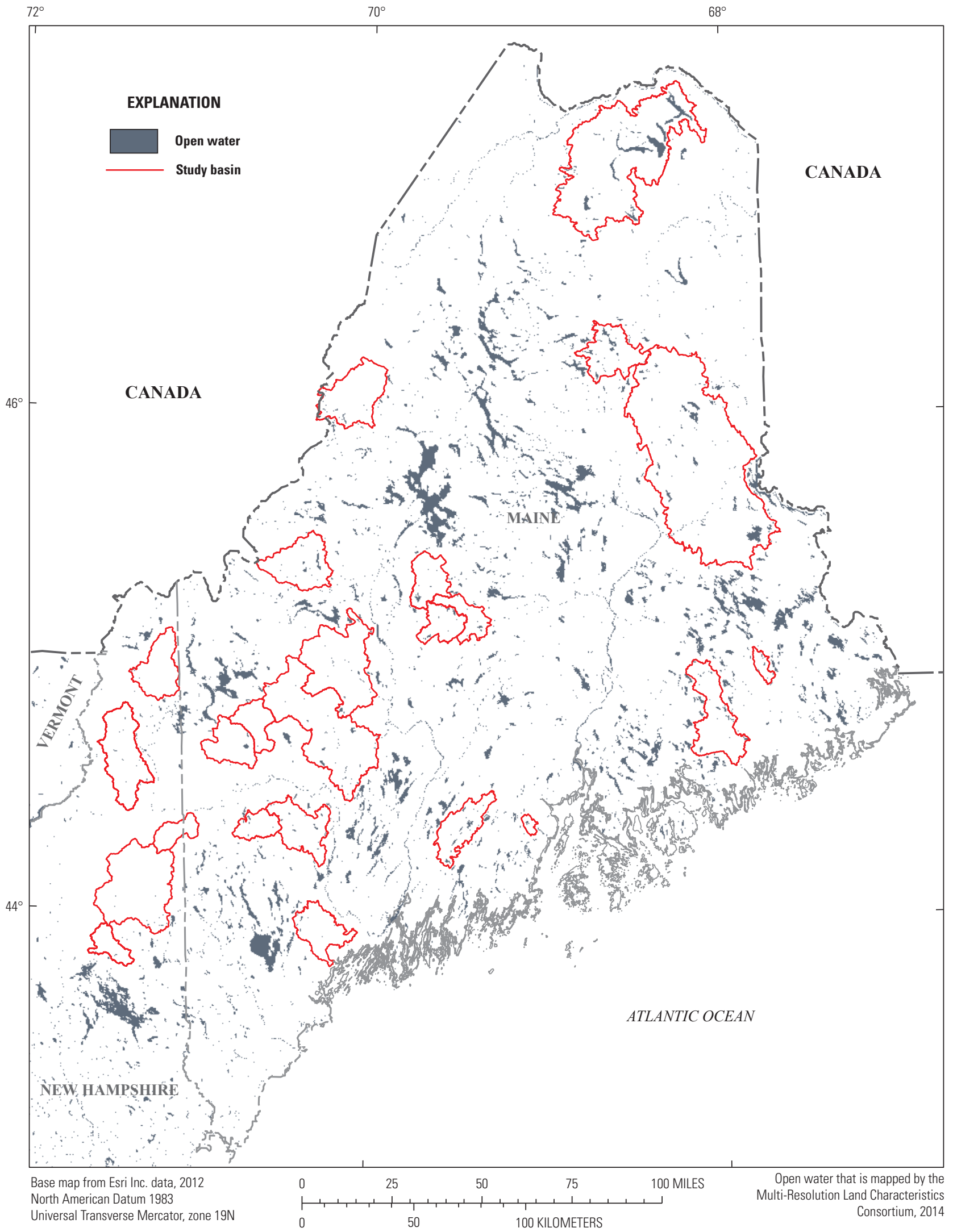

Figure 4. Distribution of land cover classified as open water (land cover code 11) in the 2006 National Land Cover Dataset (NLCD) in Maine and New Hampshire. 
the months of July, August, September, and October. For these periods, the fraction of sand and gravel aquifer provides additional explanatory power for the low-streamflow percentiles (generally median and lower). Discharge from sand and gravel aquifers (groundwater discharge, also often referred to as base flow) typically composes a substantial component of the total streamflow during low-flow periods. The distance from the coast for the drainage basin provides significant explanatory power for the variability in flows during February, March, and April. Heat in the Atlantic Ocean has a warming effect on winter air temperatures near the coast; milder temperatures in basins closer to the coast generally result in less accumulated snowpack over the winter, greater occurrence of rain during winter, and earlier snowpack melt and runoff in late winter and early spring. For February, mean basin slope provides additional, significant explanatory power for median and lower streamflows with steeper slopes contributing to higher streamflows. Percent open water is a measure of storage and provides significant explanatory power for median and higher streamflows in March and for all percentiles in April.

Percent open water continues to provide significant explanatory power for percentiles in May and June; the signs of the coefficients indicate increased amounts of open water increase low flows and decrease the highest flows. This is consistent with regression equations for estimating flood flows of various annual exceedance probabilities by Hodgkins (1999), whose equations indicate basin storage has an attenuating effect on the magnitude of flood flows. Mean basin slope provides significant explanatory power for all percentiles in May and for 25 and lower percentiles (lower flows) in June.

November, December, and January have two-variable regression equations. Maximum basin elevation adds significant explanatory power for all percentiles in November, with higher elevations corresponding with higher streamflows. The mean basin percent of HGA (well-drained soils) adds significant explanatory power for 25 and lower percentiles (lower flows) in December and 90 and lower percentiles (lower flows) in January; in all equations, higher percentages of HGA correspond with higher streamflows.

Accuracy and limitations of the equations.-The 90 percent prediction interval is a measure of uncertainty for the regression equations; it was computed by first computing the average standard error of prediction (ASEP) by taking the arithmetic mean of the standard errors of prediction for all $n$ observations (in the case of this study, $n=24$ ) for each regression equation. ASEP was then converted to a percentage for the 90 percent confidence interval, thereby representing an approximately 90 percent probability that the true value of the flow statistic at a location of interest is between the negativeand positive percent prediction intervals (tables 4-16). For example, suppose application of the annual 10 percentile flow equation ( $Q 10$, table 4$)$ for a basin of interest yields $30 \mathrm{ft}^{3} / \mathrm{s}$; there would be an approximate 90 percent probability that the true value of the annual 10 percentile streamflow is between -32.5 and +48.3 percent of $30 \mathrm{ft}^{3} / \mathrm{s}\left(20.2\right.$ to $\left.44.5 \mathrm{ft}^{3} / \mathrm{s}\right)$.

Table 4. Regression equations for estimating annual streamflows for ungaged, unregulated streams in rural drainage basins in Maine and northern New Hampshire.

$\left[(\operatorname{PRESS} / n)^{1 / 2}\right.$, prediction error sum of squares, in percent, where $n$ is the number of streamgages used in the regression equation derivation; $R^{2}$, coefficient of determination; $Q_{x}$, the streamflow estimate in cubic feet per second for x percentile, in percent; $Q_{\text {mean }}$, the mean streamflow estimate in cubic feet per second; $D A$, basin drainage area, in square miles; EAVG, mean basin elevation, in thousand meters; $S G A Q$, fraction of drainage basin area underlain by sand and gravel aquifer]

\begin{tabular}{llll}
\hline \multicolumn{1}{c}{ Regression equation } & $\begin{array}{c}\text { 90-percent } \\
\text { prediction interval } \\
\text { (percent) }\end{array}$ & $\begin{array}{c}\text { (PRESS/ } \boldsymbol{n \text { ) }} \text { (1/2 } \\
\text { (percent) }\end{array}$ & Adjusted $\boldsymbol{R}^{2}$ \\
\hline$Q_{1}=0.000913 D A^{1.54} 10^{1.42 E A V G} 10^{5.19 S G A Q}$ & -65.3 to 188 & -57.2 to 134 & 0.87 \\
$Q_{5}=0.00828 D A^{1.35} 10^{1.07 E A V G} 10^{3.21 S G A Q}$ & -43.6 to 77.2 & -34.7 to 53.3 & 0.94 \\
$Q_{10}=0.0288 D A^{1.24} 10^{0.850 E A V G} 10^{2.26 S G A Q}$ & -32.5 to 48.3 & -25.0 to 33.4 & 0.97 \\
$Q_{25}=0.210 D A^{1.07} 10^{0.456 E A V G} 10^{1.15 S G A Q}$ & -19.2 to 23.7 & -13.2 to 15.2 & 0.99 \\
$Q_{50}=0.865 D A^{0.993} 10^{0.204 E A V G} 10^{0.715 S G A Q}$ & -17.7 to 21.6 & -12.4 to 14.2 & 0.99 \\
$Q_{75}=2.34 D A^{0.984} 10^{0.108 E A V G} 10^{0.341 S G A Q}$ & -15.4 to 18.3 & -10.9 to 12.2 & 0.99 \\
$Q_{90}=5.40 D A^{0.969} 10^{0.135 E A V G} 10^{0.046 S G A Q}$ & -15.3 to 18.0 & -10.1 to 11.3 & 0.99 \\
$Q_{95}=8.61 D A^{0.956} 10^{0.188 E A V G} 10^{-0.055 S G A Q}$ & -16.3 to 19.5 & -10.4 to 11.6 & 0.99 \\
$Q_{99}=23.4 D A^{0.879} 10^{0.349 E A V G} 10^{-0.048 S G A Q}$ & -24.8 to 32.9 & -16.3 to 19.5 & 0.97 \\
$Q_{\text {mean }}=2.20 D A^{0.960} 10^{0.217 E A V G} 10^{0.253 S G A Q}$ & & & 0.99 \\
\hline
\end{tabular}


The prediction error sum of squares (PRESS) estimator of error is a measure of validation for the regression equations. PRESS is computed by summing the squares of the prediction residuals for the full set of $n$ observations. A prediction residual for the $i$ th observation is computed as the difference between the observed value of the dependent variable and the regression estimate of that variable on the basis of a regression equation derived by leaving out the $i$ th observation (therefore using $n-1$ observations to develop the equation). The prediction residuals are computed for each observation, squared and summed, yielding the PRESS statistic. The ratio PRESS $/ n$ is analogous to the average variance of prediction, and the square root of PRESS $/ n$ (converted to percent in tables 4-16) is analogous to the average standard error of prediction.

The $R^{2}$ statistic is a measure of a regression model's goodness of fit to the observations; its value ranges from 0 through 1, where 1 indicates a perfect match between the regression model estimates and the observations. An adjusted $R^{2}$ (tables 4-16) is a coefficient of determination adjusted for the degrees of freedom in the model, thereby enabling direct comparison between models with differing numbers of explanatory variables.

The largest prediction intervals and PRESS percentages are associated with regression equations for the lowest streamflows derived for months during which the lowest streamflows of the year occur (such as the 1 and 5 percentiles for August and September). Large prediction intervals for a regression equation represent large uncertainty in the regression estimate. Because of the large uncertainty in regression estimates for these lowest streamflows, there is the possibility of discontinuities to arise during application of those equations. An example of a discontinuity would be a 1 percentile regression estimate larger in magnitude that the 5 percentile estimate for the same month; this does not mean either estimate is wrong, rather, the results are simply a function of the large uncertainty in the estimates of those low flows.

The regression equations presented in this report have been derived on the basis of streamflow and basin characteristics data for unregulated, rural drainage basins without substantial streamflow or drainage modifications (for example, diversions and (or) regulation by dams or reservoirs, tile drainage, irrigation, channelization, and impervious paved surfaces). Using these equations for regulated or urbanized basins with substantial streamflow or drainage modifications will yield results of unknown error. For the study detailed in this report, regulation needed to be completely absent or deemed small enough so as to have a negligible effect on the computation of monthly statistics using daily mean streamflows. For the 24 streamgage study basins, the sum of percentages of land cover classified by the NLCD as either developed open space (land-classification code 21) or low- (code 22), medium(code 23), or high-intensity development (code 24) ranged from than 0.1 to 9.3 percent (mean of 2.3 percent). Not including developed open space, which commonly includes large-lot single-family housing units, parks, and golf courses (Fry and

Table 5. Regression equations for estimating January streamflows for ungaged, unregulated streams in rural drainage basins in Maine and northern New Hampshire.

$\left[(\operatorname{PRESS} / n)^{1 / 2}\right.$, prediction error sum of squares, in percent, where $n$ is the number of streamgages used in the regression equation derivation; $R^{2}$, coefficient of determination; $Q_{x}$, the streamflow estimate in cubic feet per second for x percentile, in percent; $Q_{\text {mean }}$, the mean streamflow estimate in cubic feet per second; $D A$, basin drainage area, in square miles; $H G A$, mean basin percentage of hydrologic soil group A]

\begin{tabular}{llll}
\hline \multicolumn{1}{c}{ Regression equation } & $\begin{array}{c}\text { 90-percent } \\
\text { prediction interval } \\
\text { (percent) }\end{array}$ & $\begin{array}{c}\text { (PRESS/ } \boldsymbol{n} \text { ) } \\
\text { (percent) }\end{array}$ & Adjusted $\boldsymbol{R}^{\mathbf{2}}$ \\
\hline$Q_{1}=0.271 D A^{0.971} 10^{0.0068 H G A}$ & -37.4 to 59.7 & -24.3 to 32.1 & 0.92 \\
$Q_{5}=0.430 D A^{0.946} 10^{0.0048 H G A}$ & -30.4 to 43.7 & -20.2 to 25.3 & 0.95 \\
$Q_{10}=0.555 D A^{0.932} 10^{0.0055 H G A}$ & -28.8 to 40.5 & -19.3 to 23.8 & 0.95 \\
$Q_{25}=0.793 D A^{0.931} 10^{0.0059 H G A}$ & -24.4 to 32.2 & -16.3 to 19.5 & 0.97 \\
$Q_{50}=1.06 D A^{0.946} 10^{0.0052 H G A}$ & -28.6 to 40.0 & -19.1 to 23.7 & 0.96 \\
$Q_{75}=1.88 D A^{0.925} 10^{0.0048 H G A}$ & -31.1 to 45.2 & -20.8 to 26.3 & 0.94 \\
$Q_{90}=4.01 D A^{0.885} 10^{0.0059 H G A}$ & -31.9 to 46.8 & -21.6 to 27.5 & 0.94 \\
$Q_{95}=9.21 D A^{0.824} 10^{0.0049 H G A}$ & -35.0 to 54.0 & -24.2 to 32.0 & 0.91 \\
$Q_{99}=27.6 D A^{0.799} 10^{0.0018 H G A}$ & -50.4 to 101 & -35.1 to 54.1 & 0.78 \\
$Q_{\text {mean }}=2.40 D A^{0.882} 10^{0.0047 H G A}$ & & & 0.96 \\
\hline
\end{tabular}


Table 6. Regression equations for estimating February streamflows for ungaged, unregulated streams in rural drainage basins in Maine and northern New Hampshire.

$\left[(\operatorname{PRESS} / n)^{1 / 2}\right.$, prediction error sum of squares, in percent, where $n$ is the number of streamgages used in the regression equation derivation; $R^{2}$, coefficient of determination; $Q_{x}$, the streamflow estimate in cubic feet per second for x percentile, in percent; $Q_{\text {mean }}$, the mean streamflow estimate in cubic feet per second; $D A$, basin drainage area, in square miles; SLOPE, mean basin slope, in percent; $D I S T$, distance from the coast, in miles, measured as the shortest distance from the drainage basin centroid to a line in the Gulf of Maine defined by end points $71 \mathrm{~W}, 42.75 \mathrm{~N}$ and $65.5 \mathrm{~W}, 45 \mathrm{~N}$, referenced to North American Datum of 1983]

\begin{tabular}{|c|c|c|c|}
\hline Regression equation & $\begin{array}{c}\text { 90-percent } \\
\text { prediction interval } \\
\text { (percent) }\end{array}$ & $\begin{array}{c}\text { (PRESS/n) }^{1 / 2} \\
\text { (percent) }\end{array}$ & Adjusted $R^{2}$ \\
\hline$Q_{1}=1.16 D A^{0.961} 10^{0.0142 S L O P E} D I S T^{-0.384}$ & -37.4 to 59.8 & -25.5 to 34.3 & 0.91 \\
\hline$Q_{5}=1.80 D A^{1.03} 10^{0.0120 S L O P E} D I S T^{-0.489}$ & -29.8 to 42.5 & -21.5 to 27.4 & 0.95 \\
\hline$Q_{10}=3.92 D A^{1.06} 10^{0.0107 S L O P E} D I S T^{-0.641}$ & -27.4 to 37.7 & -19.6 to 24.4 & 0.96 \\
\hline$Q_{25}=7.06 D A^{1.09} 10^{0.0086 S L O P E} D I S T^{-0.718}$ & -23.6 to 30.9 & -17.2 to 20.8 & 0.97 \\
\hline$Q_{50}=12.8 D A^{1.09} 10^{0.0058 S L O P E} D I S T^{-0.762}$ & -20.0 to 25.1 & -13.9 to 16.1 & 0.98 \\
\hline$Q_{75}=30.8 D A^{1.05} 10^{0.0020 S L O P E} D I S T^{-0.785}$ & -14.5 to 16.9 & -9.90 to 11.0 & 0.99 \\
\hline$Q_{90}=87.1 D A^{1.04} 10^{0.0001 S L O P E} D I S T^{-0.879}$ & -19.7 to 24.5 & -14.1 to 16.4 & 0.98 \\
\hline$Q_{95}=244 D A^{0.968} 10^{-0.0002 S L O P E} D I S T^{-0.923}$ & -25.9 to 34.9 & -18.5 to 22.7 & 0.96 \\
\hline$Q_{99}=647 D A^{0.880} 10^{0.0057 S L O P E} D I S T^{-0.902}$ & -35.5 to 55.1 & -26.4 to 35.8 & 0.90 \\
\hline$Q_{\text {mean }}=35.9 D A^{1.02} 10^{0.0041 S L O P E} D I S T^{-0.814}$ & -15.9 to 18.8 & -11.4 to 12.9 & 0.99 \\
\hline
\end{tabular}

Table 7. Regression equations for estimating March streamflows for ungaged, unregulated streams in rural drainage basins in Maine and northern New Hampshire.

[(PRESS $/ n)^{1 / 2}$, prediction error sum of squares, in percent, where $n$ is the number of streamgages used in the regression equation derivation; $R^{2}$, coefficient of determination; $Q_{x}$, the streamflow estimate in cubic feet per second for x percentile, in percent; $Q_{\text {mean }}$, the mean streamflow estimate in cubic feet per second; $D A$, basin drainage area, in square miles; WATER, percent of drainage basin land cover classified as open water (National Land Cover Data land-classification code 11); DIST, distance from the coast, in miles, measured as the shortest distance from the drainage basin centroid to a line in the Gulf of Maine defined by end points $71 \mathrm{~W}, 42.75 \mathrm{~N}$ and $65.5 \mathrm{~W}$, $45 \mathrm{~N}$, referenced to North American Datum of 1983]

\begin{tabular}{|c|c|c|c|}
\hline Regression equation & $\begin{array}{l}\text { 90-percent } \\
\text { prediction interval } \\
\text { (percent) }\end{array}$ & $\begin{array}{c}\text { (PRESS/n) }^{1 / 2} \\
(\text { percent) }\end{array}$ & Adjusted $R$ \\
\hline$Q_{1}=5.83 D A^{1.02} 10^{-0.0034 W A T E R} D I S T^{-0.676}$ & -36.5 to 57.4 & -27.5 to 37.9 & 0.92 \\
\hline$Q_{5}=8.42 D A^{1.03} 10^{-0.0122 W A T E R} D I S T^{-0.698}$ & -32.3 to 47.7 & -23.8 to 31.2 & 0.94 \\
\hline$Q_{10}=13.4 D A^{1.00} 10^{-0.0129 \text { WATER }} D I S T^{-0.720}$ & -26.3 to 35.7 & -19.2 to 23.8 & 0.96 \\
\hline$Q_{25}=36.2 D A^{0.990} 10^{-0.0117 W A T E R} D I S T^{-0.829}$ & -20.7 to 26.0 & -14.5 to 17.0 & 0.98 \\
\hline$Q_{50}=159 D A^{1.01} 10^{-0.0116 \text { WATER }} D I S T^{-1.02}$ & -17.7 to 21.5 & -11.7 to 13.3 & 0.98 \\
\hline$Q_{75}=274 D A^{0.992} 10^{-0.0286 \text { WATER }} D I S T^{0.958}$ & -21.5 to 27.4 & -15.5 to 18.4 & 0.97 \\
\hline$Q_{90}=259 D A^{0.930} 10^{-0.0427 \text { WATER }} D I S T^{-0.721}$ & -24.8 to 32.9 & -18.6 to 22.8 & 0.96 \\
\hline$Q_{95}=225 D A^{0.913} 10^{-0.0540 \text { WATER }} D I S T^{-0.583}$ & -30.0 to 42.8 & -22.1 to 28.3 & 0.94 \\
\hline$Q_{99}=109 D A^{0.807} 10^{-0.0744 \text { WATER }} D I S T^{-0.126}$ & -27.6 to 38.1 & -20.3 to 25.5 & 0.94 \\
\hline$Q_{\text {mean }}=103 D A^{0.940} 10^{-0.0392 \text { WATER }} D I S T^{-0.706}$ & -18.9 to 23.3 & -13.7 to 15.8 & 0.98 \\
\hline
\end{tabular}


Table 8. Regression equations for estimating April streamflows for ungaged, unregulated streams in rural drainage basins in Maine and northern New Hampshire.

$\left[(\operatorname{PRESS} / n)^{1 / 2}\right.$, prediction error sum of squares, in percent, where $n$ is the number of streamgages used in the regression equation derivation; $R^{2}$, coefficient of determination; $Q_{x}$, the streamflow estimate in cubic feet per second for x percentile, in percent; $Q_{\text {mean }}$, the mean streamflow estimate in cubic feet per second; $D A$, basin drainage area, in square miles; WATER, percent of drainage basin land cover classified as open water (National Land Cover Data land-classification code 11); DIST, distance from the coast, in miles, measured as the shortest distance from the drainage basin centroid to a line in the Gulf of Maine defined by end points $71 \mathrm{~W}, 42.75 \mathrm{~N}$ and $65.5 \mathrm{~W}, 45 \mathrm{~N}$, referenced to North American Datum of 1983]

\begin{tabular}{|c|c|c|c|}
\hline Regression equation & $\begin{array}{c}\text { 90-percent } \\
\text { prediction interval } \\
\text { (percent) }\end{array}$ & $\begin{array}{c}(\text { PRESS/n) })^{1 / 2} \\
(\text { percent) }\end{array}$ & Adjusted $R^{2}$ \\
\hline$Q_{1}=3.92 D A^{1.12} 10^{-0.0468 \text { WATER }} D I S T^{-0.432}$ & -31.0 to 44.8 & -22.1 to 28.4 & 0.96 \\
\hline$Q_{5}=3.32 D A^{1.14} 10^{-0.0475 \text { WATER }} D I S T^{-0.313}$ & -30.2 to 43.3 & -23.4 to 30.6 & 0.96 \\
\hline$Q_{10}=3.22 D A^{1.12} 10^{-0.0415 \text { WATER }} D I S T^{-0.233}$ & -24.0 to 31.5 & -18.7 to 23.0 & 0.98 \\
\hline$Q_{25}=2.13 D A^{1.06} 10^{-0.0291 \text { WATER }} D I S T^{0.011}$ & -21.1 to 26.8 & -17.1 to 20.7 & 0.98 \\
\hline$Q_{50}=1.14 D A^{1.02} 10^{-0.0113 \text { WATER }} D I S T^{0.292}$ & -19.5 to 24.2 & -14.4 to 16.9 & 0.99 \\
\hline$Q_{75}=1.59 D A^{0.971} 10^{-0.0207 W A T E R} D I S T^{0.404}$ & -19.5 to 24.2 & -13.7 to 15.9 & 0.99 \\
\hline$Q_{90}=3.39 D A^{0.924} 10^{-0.0374 W A T E R} D I S T^{0.412}$ & -18.2 to 22.3 & -12.4 to 14.2 & 0.99 \\
\hline$Q_{95}=6.51 D A^{0.894} 10^{-0.0443 \text { WATER }} D I S T^{0.370}$ & -16.8 to 20.2 & -11.2 to 12.6 & 0.99 \\
\hline$Q_{99}=39.5 D A^{0.822} 10^{-0.0518 W A T E R} D I S T^{0.170}$ & -26.6 to 36.2 & -19.0 to 23.4 & 0.96 \\
\hline$Q_{\text {mean }}=2.33 D A^{0.964} 10^{-0.0283 \text { WATER }} D I S T^{0.286}$ & -16.7 to 20.0 & -12.0 to 13.6 & 0.99 \\
\hline
\end{tabular}

Table 9. Regression equations for estimating May streamflows for ungaged, unregulated streams in rural drainage basins in Maine and northern New Hampshire.

$\left[(\operatorname{PRESS} / n)^{1 / 2}\right.$, prediction error sum of squares, in percent, where $n$ is the number of streamgages used in the regression equation derivation; $R^{2}$, coefficient of determination; $Q_{x}$, the streamflow estimate in cubic feet per second for x percentile, in percent; $Q_{\text {mean }}$, the mean streamflow estimate in cubic feet per second; $D A$, basin drainage area, in square miles; WATER, percent of drainage basin land cover classified as open water (National Land Cover Data land-classification code 11); SLOPE, mean basin slope, in percent]

\begin{tabular}{|c|c|c|c|}
\hline Regression equation & $\begin{array}{c}\text { 90-percent } \\
\text { prediction interval } \\
\text { (percent) }\end{array}$ & $\begin{array}{c}\text { (PRESS/n) }^{1 / 2} \\
\text { (percent) }\end{array}$ & Adjusted $R^{2}$ \\
\hline$Q_{1}=0.0913 D A^{1.20} 10^{0.0373 W A T E R} 10^{0.0233 S L O P E}$ & -33.7 to 50.9 & -21.9 to 28.0 & 0.96 \\
\hline$Q_{5}=0.158 D A^{1.17} 10^{0.0430 \text { WATER }} 10^{0.0224 \text { SLOPE }}$ & -28.4 to 39.7 & -20.1 to 25.2 & 0.97 \\
\hline$Q_{10}=0.216 D A^{1.15} 10^{0.0462 W A T E R} 10^{0.0219 S L O P E}$ & -26.4 to 35.9 & -18.6 to 22.8 & 0.98 \\
\hline$Q_{25}=0.362 D A^{1.13} 10^{0.0507 W A T E R} 10^{0.0208 S L O P E}$ & -22.4 to 28.8 & -15.6 to 18.5 & 0.98 \\
\hline$Q_{50}=0.615 D A^{1.13} 10^{0.0457 W A T E R} 10^{0.0190 S L O P E}$ & -19.6 to 24.4 & -12.7 to 14.5 & 0.99 \\
\hline$Q_{75}=1.10 D A^{1.12} 10^{0.0397 W A T E R} 10^{0.0175 S L O P E}$ & -21.4 to 27.3 & -13.8 to 16.0 & 0.98 \\
\hline$Q_{90}=2.14 D A^{1.10} 10^{0.0253 \text { WATER }} 10^{0.0161 \text { SLOPE }}$ & -25.6 to 34.4 & -16.8 to 20.2 & 0.98 \\
\hline$Q_{95}=3.67 D A^{1.06} 10^{0.0181 \text { WATER }} 10^{0.0160 \text { SLOPE }}$ & -26.4 to 35.8 & -17.4 to 21.0 & 0.97 \\
\hline$Q_{99}=9.39 D A^{1.02} 10^{-0.0039 \text { WATER }} 10^{0.0139 S L O P E}$ & -23.4 to 30.6 & -16.0 to 19.1 & 0.98 \\
\hline$Q_{\text {mean }}=1.07 D A^{1.10} 10^{0.0323 W A T E R} 10^{0.0174 S L O P E}$ & -20.4 to 25.6 & -13.3 to 15.4 & 0.99 \\
\hline
\end{tabular}


Table 10. Regression equations for estimating June streamflows for ungaged, unregulated streams in rural drainage basins in Maine and northern New Hampshire.

[(PRESS $/ n)^{1 / 2}$, prediction error sum of squares, in percent, where $n$ is the number of streamgages used in the regression equation derivation; $R^{2}$, coefficient of determination; $Q_{x}$, the streamflow estimate in cubic feet per second for x percentile, in percent; $Q_{\text {mean }}$, the mean streamflow estimate in cubic feet per second; $D A$, basin drainage area, in square miles; WATER, percent of drainage basin land cover classified as open water (National Land Cover Data land-classification code 11); SLOPE, mean basin slope, in percent]

\begin{tabular}{|c|c|c|c|}
\hline Regression equation & $\begin{array}{c}\text { 90-percent } \\
\text { prediction interval } \\
\text { (percent) }\end{array}$ & $\begin{array}{c}\text { (PRESS/n) }^{1 / 2} \\
\text { (percent) }^{\text {pent }}\end{array}$ & Adjusted $R^{2}$ \\
\hline$Q_{1}=0.0689 D A^{1.15} 10^{0.0328 W A T E R} 10^{0.0173 S L O P E}$ & -46.5 to 86.8 & -34.0 to 51.6 & 0.91 \\
\hline$Q_{5}=0.0922 D A^{1.13} 10^{0.0405 W A T E R} 10^{0.0197 S L O P E}$ & -38.9 to 63.7 & -28.1 to 39.1 & 0.94 \\
\hline$Q_{10}=0.109 D A^{1.14} 10^{0.0394 W A T E R} 10^{0.0195 S L O P E}$ & -35.2 to 54.4 & -25.0 to 33.4 & 0.95 \\
\hline$Q_{25}=0.188 D A^{1.13} 10^{0.0312 \text { WATER }} 10^{0.0178 S L O P E}$ & -28.1 to 39.2 & -19.5 to 24.2 & 0.97 \\
\hline$Q_{50}=0.384 D A^{1.10} 10^{0.0258 W A T E R} 10^{0.0147 S L O P E}$ & -23.3 to 30.3 & -15.9 to 18.9 & 0.98 \\
\hline$Q_{75}=1.12 D A^{1.04} 10^{0.0165 \text { WATER }} 10^{0.0108 S L O P E}$ & -24.1 to 31.7 & -17.5 to 20.5 & 0.98 \\
\hline$Q_{90}=3.64 D A^{0.970} 10^{-0.0026 \text { WATER }} 10^{0.0074 S L O P E}$ & -27.9 to 38.8 & -20.0 to 25.0 & 0.96 \\
\hline$Q_{95}=8.95 D A^{0.920} 10^{-0.0253 \text { WATER }} 10^{0.0029 S L O P E}$ & -28.3 to 39.4 & -20.4 to 25.6 & 0.96 \\
\hline$Q_{99}=35.8 D A^{0.882} 10^{-0.0780 \text { WATER }} 10^{-0.0017 S L O P E}$ & -35.8 to 55.9 & -25.4 to 34.0 & 0.92 \\
\hline$Q_{\text {mean }}=1.41 D A^{1.00} 10^{0.0006 \text { WATER }} 10^{0.0104 S L O P E}$ & -18.6 to 22.9 & -13.6 to 15.7 & 0.98 \\
\hline
\end{tabular}

Table 11. Regression equations for estimating July streamflows for ungaged, unregulated streams in rural drainage basins in Maine and northern New Hampshire.

$\left[(\mathrm{PRESS} / n)^{1 / 2}\right.$, prediction error sum of squares, in percent, where $n$ is the number of streamgages used in the regression equation derivation; $R^{2}$, coefficient of determination; $Q_{x}$, the streamflow estimate in cubic feet per second for x percentile, in percent; $Q_{\text {mean }}$, the mean streamflow estimate in cubic feet per second; $D A$, basin drainage area, in square miles; $E A V G$, mean basin elevation, in thousands of meters; $S G A Q$, fraction of drainage basin area underlain by sand and gravel aquifer]

\begin{tabular}{lccc}
\hline \multicolumn{1}{c}{ Regression equation } & $\begin{array}{c}\text { 90-percent } \\
\text { prediction interval } \\
\text { (percent) }\end{array}$ & $\begin{array}{c}\text { (PRESS/ } \boldsymbol{n} \text { )/2 } \\
\text { (percent) }\end{array}$ & Adjusted $\boldsymbol{R}^{\mathbf{2}}$ \\
\hline$Q_{1}=0.0061 D A^{1.38} 10^{0.891 E A V G} 10^{3.04 S G A Q}$ & -55.5 to 125 & -42.9 to 75.1 & 0.90 \\
$Q_{5}=0.0148 D A^{1.31} 10^{0.788 E A V G} 10^{2.48 S G A Q}$ & -49.9 to 99.6 & -36.6 to 57.8 & 0.91 \\
$Q_{10}=0.0207 D A^{1.30} 10^{0.745 E A V G} 10^{2.07 S G A Q}$ & -44.3 to 79.5 & -31.5 to 45.9 & 0.94 \\
$Q_{25}=0.0382 D A^{1.27} 10^{0.656 E A V G} 10^{1.51 S G A Q}$ & -37.0 to 58.8 & -25.3 to 33.9 & 0.96 \\
$Q_{50}=0.105 D A^{1.20} 10^{0.586 E A V G} 10^{0.781 S G A Q}$ & -29.9 to 42.7 & -20.1 to 25.2 & 0.97 \\
$Q_{75}=0.363 D A^{1.11} 10^{0.499 E A V G} 10^{0.001 S G A Q}$ & -26.3 to 35.7 & -18.5 to 22.7 & 0.98 \\
$Q_{90}=1.08 D A^{1.05} 10^{0.474 E A V G} 10^{-0.070 S G A Q}$ & -24.3 to 32.1 & -17.8 to 21.7 & 0.98 \\
$Q_{95}=2.11 D A^{1.01} 10^{0.463 E A V G} 10^{-0.044 S G A Q}$ & -27.2 to 37.3 & -19.2 to 23.7 & 0.97 \\
$Q_{99}=6.35 D A^{0.926} 10^{0.593 E A V G} 10^{0.048 S G A Q}$ & -42.8 to 74.7 & -31.0 to 44.9 & 0.89 \\
$Q_{\text {mean }}=0.432 D A^{1.08} 10^{0.508 E A V G} 10^{0.165 S G A Q}$ & & -14.4 to 16.8 & 0.99 \\
\hline
\end{tabular}


Table 12. Regression equations for estimating August streamflows for ungaged, unregulated streams in rural drainage basins in Maine and northern New Hampshire.

$\left[(\operatorname{PRESS} / n)^{1 / 2}\right.$, prediction error sum of squares, in percent, where $n$ is the number of streamgages used in the regression equation derivation; $R^{2}$, coefficient of determination; $Q_{x}$, the streamflow estimate in cubic feet per second for x percentile, in percent; $Q_{\text {mean }}$, the mean streamflow estimate in cubic feet per second; $D A$, basin drainage area, in square miles; $E A V G$, mean basin elevation, in thousands of meters; $S G A Q$, fraction of drainage basin area underlain by sand and gravel aquifer]

\begin{tabular}{|c|c|c|c|}
\hline Regression equation & $\begin{array}{c}\text { 90-percent } \\
\text { prediction interval } \\
\text { (percent) }\end{array}$ & $\begin{array}{c}\text { (PRESS/n) }^{1 / 2} \\
(\text { percent) }\end{array}$ & Adjusted $R^{2}$ \\
\hline$Q_{1}=0.000136 D A^{1.77} 10^{1.66 E A V G} 10^{6.56 S G A Q}$ & -78.8 to 373 & -71.4 to 250 & 0.80 \\
\hline$Q_{5}=0.000774 D A^{1.60} 10^{1.36 E A V G} 10^{4.87 S G A Q}$ & -67.0 to 203 & -58.0 to 138 & 0.86 \\
\hline$Q_{10}=0.00136 D A^{1.56} 10^{1.28 E A V G} 10^{4.46 S G A Q}$ & -62.9 to 170 & -53.7 to 116 & 0.88 \\
\hline$Q_{25}=0.0108 D A^{1.36} 10^{0.926 E A V G} 10^{2.80 S G A Q}$ & -42.4 to 73.6 & -31.3 to 45.5 & 0.95 \\
\hline$Q_{50}=0.0339 D A^{1.27} 10^{0.831 E A V G} 10^{1.87 S G A Q}$ & -32.0 to 47.1 & -23.0 to 29.9 & 0.97 \\
\hline$Q_{75}=0.157 D A^{1.17} 10^{0.720 E A V G} 10^{0.655 S G A Q}$ & -28.5 to 39.9 & -19.3 to 23.8 & 0.97 \\
\hline$Q_{90}=0.497 D A^{1.12} 10^{0.717 E A V G} 10^{0.053 S G A Q}$ & -29.4 to 41.6 & -20.4 to 25.6 & 0.97 \\
\hline$Q_{95}=0.903 D A^{1.09} 10^{0.779 E A V G} 10^{0.233 S G A Q}$ & -28.5 to 39.8 & -19.5 to 24.2 & 0.97 \\
\hline$Q_{99}=4.00 D A^{0.945} 10^{0.914 E A V G} 10^{0.780 S G A Q}$ & -42.1 to 72.7 & -29.8 to 42.5 & 0.91 \\
\hline$Q_{\text {mean }}=0.206 D A^{1.11} 10^{0.811 E A V G} 10^{0.905 S G A Q}$ & -28.0 to 38.8 & -19.1 to 23.7 & 0.97 \\
\hline
\end{tabular}

Table 13. Regression equations for estimating September streamflows for ungaged, unregulated streams in rural drainage basins in Maine and northern New Hampshire.

$\left[(\mathrm{PRESS} / n)^{1 / 2}\right.$, prediction error sum of squares, in percent, where $n$ is the number of streamgages used in the regression equation derivation; $R^{2}$, coefficient of determination; $Q_{x}$, the streamflow estimate in cubic feet per second for x percentile, in percent; $Q_{\text {mean }}$, the mean streamflow estimate in cubic feet per second; $D A$, basin drainage area, in square miles; $E A V G$, mean basin elevation, in thousands of meters; $S G A Q$, fraction of drainage basin area underlain by sand and gravel aquifer]

\begin{tabular}{llll}
\hline \multicolumn{1}{c}{ Regression equation } & $\begin{array}{c}\text { 90-percent } \\
\text { prediction interval } \\
\text { (percent) }\end{array}$ & $\begin{array}{c}\text { (PRESS/ } \boldsymbol{n} \text { ) } \\
\text { (percent) }\end{array}$ & Adjusted $\boldsymbol{R}^{\mathbf{2}}$ \\
\hline$Q_{1}=0.00013 D A^{1.72} 10^{1.65 E A V G} 10^{6.96 S G A Q}$ & -78.3 to 360 & -70.5 to 238 & 0.80 \\
$Q_{5}=0.000199 D A^{1.73} 10^{1.71 E A V G} 10^{6.28 S G A Q}$ & -78.7 to 369 & -72.6 to 265 & 0.80 \\
$Q_{10}=0.00217 D A^{1.45} 10^{1.29 E A V G} 10^{4.54 S G A Q}$ & -57.9 to 138 & -49.2 to 97.0 & 0.90 \\
$Q_{25}=0.00865 D A^{1.33} 10^{1.18 E A V G} 10^{3.17 S G A Q}$ & -44.6 to 80.6 & -35.4 to 54.9 & 0.94 \\
$Q_{50}=0.0380 D A^{1.21} 10^{0.990 E A V G} 10^{2.09 S G A Q}$ & -29.3 to 41.5 & -22.2 to 28.5 & 0.97 \\
$Q_{75}=0.203 D A^{1.08} 10^{0.759 E A V G} 10^{0.901 S G A Q}$ & -22.6 to 29.1 & -15.2 to 17.9 & 0.98 \\
$Q_{90}=0.575 D A^{1.04} 10^{0.711 E A V G} 10^{0.329 S G A Q}$ & -30.9 to 44.7 & -21.1 to 26.7 & 0.96 \\
$Q_{95}=1.29 D A^{1.01} 10^{0.596 E A V G} 10^{-0.067 S G A Q}$ & -34.2 to 52.1 & -23.3 to 30.3 & 0.95 \\
$Q_{99}=6.84 D A^{0.892} 10^{0.522 E A V G} 10^{0.207 S G A Q}$ & -45.5 to 83.6 & -31.2 to 45.4 & 0.87 \\
$Q_{\text {mean }}=0.279 D A^{1.04} 10^{0.729 E A V G} 10^{0.795 S G A Q}$ & & & 0.97 \\
\hline
\end{tabular}


Table 14. Regression equations for estimating October streamflows for ungaged, unregulated streams in rural drainage basins in Maine and northern New Hampshire.

[(PRESS $/ n)^{1 / 2}$, prediction error sum of squares, in percent, where $n$ is the number of streamgages used in the regression equation derivation; $R^{2}$, coefficient of determination; $Q_{x}$, the streamflow estimate in cubic feet per second for x percentile, in percent; $Q_{\text {mean }}$, the mean streamflow estimate in cubic feet per second; $D A$, basin drainage area, in square miles; $E A V G$, mean basin elevation, in thousands of meters; $S G A Q$, fraction of drainage basin area underlain by sand and gravel aquifer]

\begin{tabular}{|c|c|c|c|}
\hline Regression equation & $\begin{array}{c}\text { 90-percent } \\
\text { prediction interval } \\
\text { (percent) }\end{array}$ & $\begin{array}{c}\text { (PRESS/n) }^{1 / 2} \\
(\text { percent) }\end{array}$ & Adjusted $R^{2}$ \\
\hline$Q_{1}=0.00303 D A^{1.33} 10^{1.52 E A V G} 10^{4.93 S G A Q}$ & -62.8 to 169 & -56.0 to 127 & 0.86 \\
\hline$Q_{5}=0.00476 D A^{1.36} 10^{1.38 E A V G} 10^{3.93 S G A Q}$ & -59.0 to 144 & -52.2 to 109 & 0.88 \\
\hline$Q_{10}=0.0142 D A^{1.27} 10^{1.18 E A V G} 10^{2.78 S G A Q}$ & -44.1 to 79.0 & -37.4 to 59.8 & 0.94 \\
\hline$Q_{25}=0.0759 D A^{1.13} 10^{0.869 E A V G} 10^{1.75 S G A Q}$ & -23.7 to 31.1 & -17.0 to 20.5 & 0.98 \\
\hline$Q_{50}=0.366 D A^{1.02} 10^{0.658 E A V G} 10^{0.566 S G A Q}$ & -27.2 to 37.3 & -19.2 to 23.8 & 0.97 \\
\hline$Q_{75}=1.53 D A^{0.951} 10^{0.455 E A V G} 10^{-0.002 S G A Q}$ & -31.1 to 45.2 & -22.7 to 29.4 & 0.95 \\
\hline$Q_{90}=4.60 D A^{0.896} 10^{0.447 E A V G} 10^{-0.159 S G A Q}$ & -35.9 to 56.0 & -24.8 to 33.0 & 0.92 \\
\hline$Q_{95}=9.43 D A^{0.841} 10^{0.499 E A V G} 10^{-0.082 S G A Q}$ & -35.1 to 54.0 & -23.1 to 30.1 & 0.92 \\
\hline$Q_{99}=30.8 D A^{0.784} 10^{0.578 E A V G} 10^{-0.218 S G A Q}$ & -42.9 to 75.2 & -29.2 to 41.2 & 0.86 \\
\hline$Q_{\text {mean }}=1.91 D A^{0.895} 10^{0.526 E A V G} 10^{0.083 S G A Q}$ & -28.9 to 40.6 & -19.6 to 24.4 & 0.96 \\
\hline
\end{tabular}

Table 15. Regression equations for estimating November streamflows for ungaged, unregulated streams in rural drainage basins in Maine and northern New Hampshire.

$\left[(\mathrm{PRESS} / \mathrm{n})^{1 / 2}\right.$, prediction error sum of squares, in percent, where $n$ is the number of streamgages used in the regression equation derivation; $R^{2}$, coefficient of determination; $Q_{x}$, the streamflow estimate in cubic feet per second for x percentile, in percent; $Q_{\text {mean }}$, the mean streamflow estimate in cubic feet per second; $D A$, basin drainage area, in square miles; EMAX, maximum basin elevation, in thousands of meters]

\begin{tabular}{llll}
\hline \multicolumn{1}{c}{ Regression equation } & $\begin{array}{c}\text { 90-percent } \\
\text { prediction interval } \\
\text { (percent) }\end{array}$ & $\begin{array}{c}\text { (PRESS/ } \boldsymbol{n} \text { ) } \\
\text { (percent) }\end{array}$ & Adjusted $\boldsymbol{R}^{\mathbf{2}}$ \\
\hline$Q_{1}=0.0514 D A^{1.13} 10^{0.376 E M A X}$ & -65.0 to 185 & -55.1 to 123 & 0.80 \\
$Q_{5}=0.100 D A^{1.10} 10^{0.342 E M A X}$ & -54.2 to 118 & -43.2 to 76.1 & 0.87 \\
$Q_{10}=0.290 D A^{1.02} 10^{0.246 \text { EMAX }}$ & -34.7 to 53.2 & -24.8 to 33.0 & 0.95 \\
$Q_{25}=0.977 D A^{0.937} 10^{0.146 E M A X}$ & -27.0 to 37.0 & -17.3 to 20.9 & 0.96 \\
$Q_{50}=1.87 D A^{0.955} 10^{0.081 E M A X}$ & -21.0 to 26.6 & -14.4 to 16.9 & 0.98 \\
$Q_{75}=3.65 D A^{0.949} 10^{0.050 E M A X}$ & -19.0 to 23.4 & -12.6 to 14.5 & 0.98 \\
$Q_{90}=7.74 D A^{0.901} 10^{0.064 E M A X}$ & -22.5 to 29.0 & -14.4 to 16.8 & 0.97 \\
$Q_{95}=12.3 D A^{0.867} 10^{0.094 E M A X}$ & -30.4 to 43.6 & -19.7 to 24.6 & 0.94 \\
$Q_{99}=33.1 D A^{0.758} 10^{0.182 E M A X}$ & -41.9 to 72.0 & -28.4 to 39.6 & 0.86 \\
$Q_{\text {mean }}=3.49 D A^{0.902} 10^{0.099 E M A X}$ & & & 0.98 \\
\hline
\end{tabular}


Table 16. Regression equations for estimating December streamflows for ungaged, unregulated streams in rural drainage basins in Maine and northern New Hampshire.

$\left[(\operatorname{PRESS} / n)^{1 / 2}\right.$, prediction error sum of squares, in percent, where $n$ is the number of streamgages used in the regression equation derivation; $R^{2}$, coefficient of determination; $Q_{x}$, the streamflow estimate in cubic feet per second for x percentile, in percent; $Q_{\text {mean }}$, the mean streamflow estimate in cubic feet per second; $D A$, basin drainage area, in square miles; $H G A$, mean basin percentage of hydrologic soil group A]

\begin{tabular}{llll}
\hline \multicolumn{1}{c}{ Regression equation } & $\begin{array}{c}\text { 90-percent } \\
\text { prediction interval } \\
\text { (percent) }\end{array}$ & $\begin{array}{c}\text { (PRESS/ } \boldsymbol{n} \text { ) } \\
\text { (percent) }\end{array}$ & Adjusted $\boldsymbol{R}^{\mathbf{2}}$ \\
\hline$Q_{1}=0.0516 D A^{1.28} 10^{0.0132 H G A}$ & -58.6 to 142 & -48.7 to 95.0 & 0.85 \\
$Q_{5}=0.222 D A^{1.11} 10^{0.0083 H G A}$ & -27.6 to 38.2 & -19.9 to 24.9 & 0.97 \\
$Q_{10}=0.573 D A^{0.986} 10^{0.0047 H G A}$ & -22.7 to 29.4 & -15.8 to 18.7 & 0.98 \\
$Q_{25}=1.12 D A^{0.935} 10^{0.0036 H G A}$ & -23.2 to 30.2 & -15.8 to 18.7 & 0.97 \\
$Q_{50}=1.92 D A^{0.936} 10^{0.0021 H G A}$ & -28.9 to 40.6 & -19.5 to 24.2 & 0.96 \\
$Q_{75}=2.90 D A^{0.955} 10^{0.0032 H G A}$ & -31.6 to 46.1 & -21.9 to 28.1 & 0.95 \\
$Q_{90}=5.46 D A^{0.943} 10^{0.0038 H G A}$ & -31.6 to 46.2 & -21.6 to 27.5 & 0.94 \\
$Q_{95}=10.8 D A^{0.888} 10^{0.0037 H G A}$ & -30.4 to 43.8 & -20.8 to 26.3 & 0.94 \\
$Q_{99}=27.6 D A^{0.855} 10^{0.0059 H G A}$ & -43.0 to 75.5 & -29.3 to 41.3 & 0.86 \\
$Q_{\text {mean }}=3.16 D A^{0.921} 10^{0.0035 H G A}$ & & & 0.97 \\
\hline
\end{tabular}



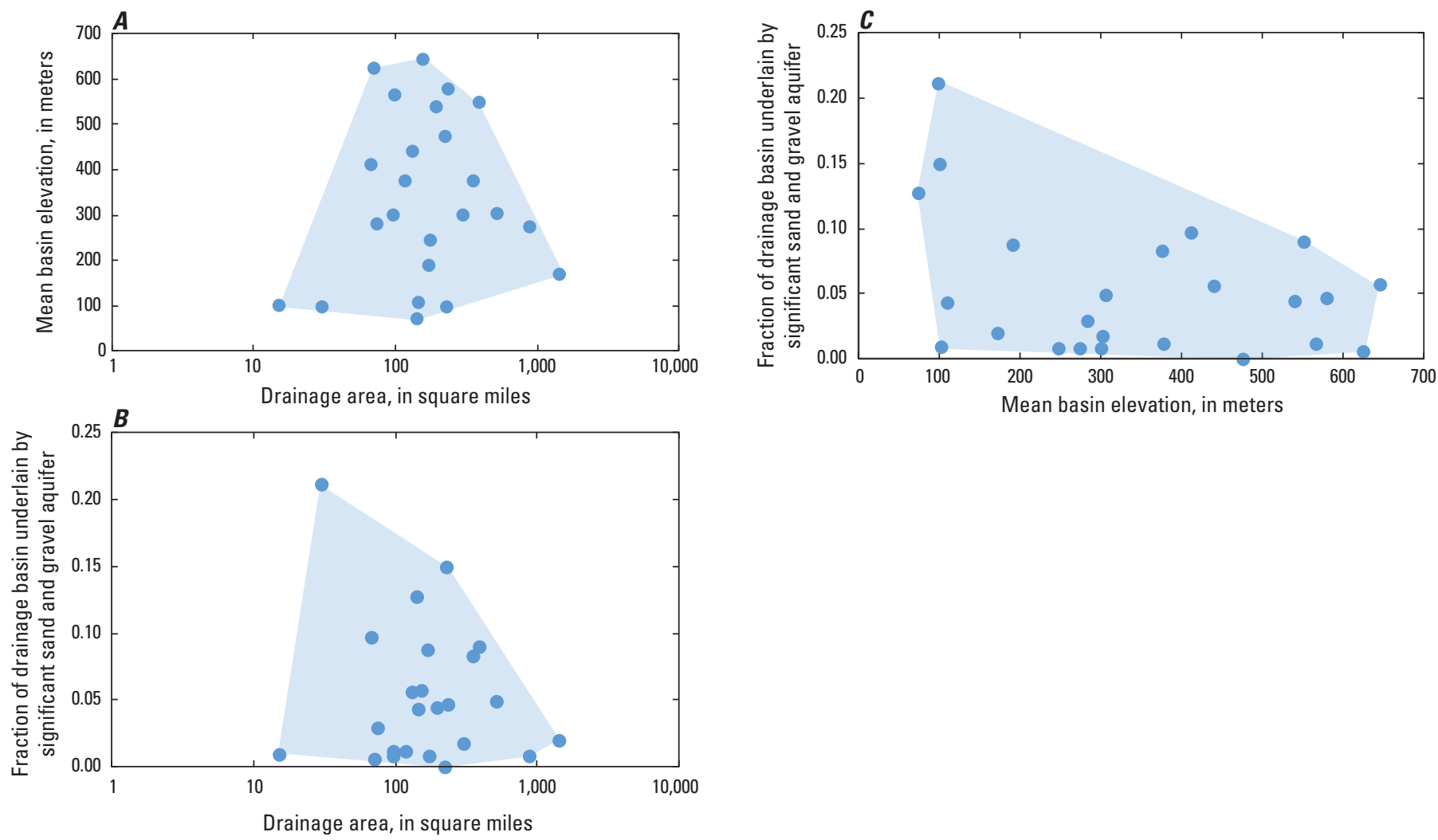

Figure 5. Two-dimensional ranges of explanatory variables used in regression equations for estimating annual and July, August, September, and October mean and selected percentile streamflows for ungaged, unregulated streams in rural drainage basins in Maine and northern New Hampshire.

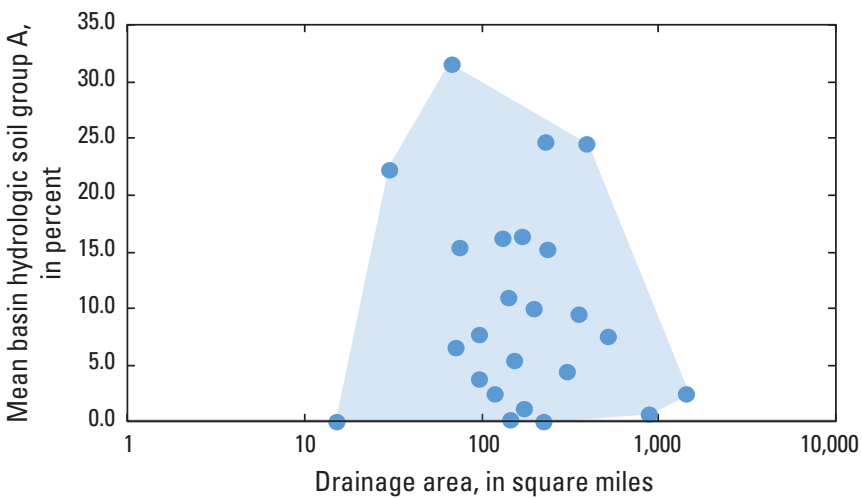

Figure 6. Two-dimensional range of explanatory variables used in regression equations for estimating January and December mean and selected percentile streamflows for ungaged, unregulated streams in rural drainage basins in Maine and northern New Hampshire. 

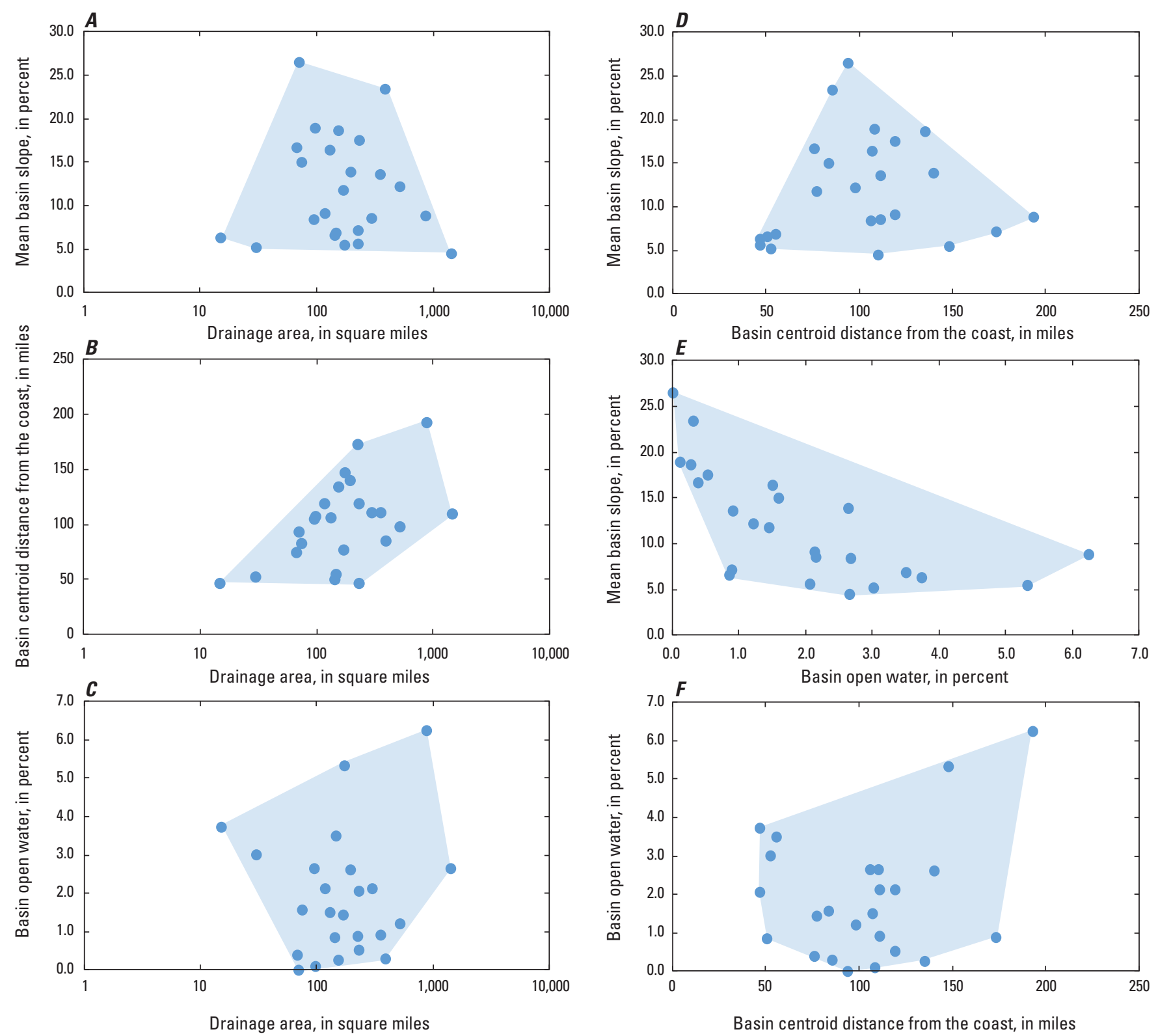

Figure 7. Two-dimensional ranges of explanatory variables used in regression equations for estimating February, March, April, May, and June mean and selected percentile streamflows for ungaged, unregulated streams in rural drainage basins in Maine and northern New Hampshire.

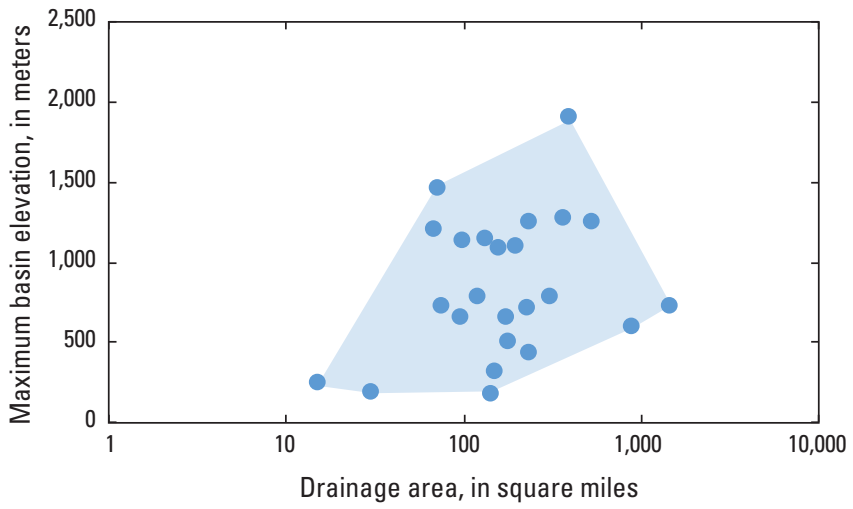

Figure 8. Two-dimensional range of explanatory variables used in regression equations for estimating November mean and selected percentile streamflows for ungaged, unregulated streams in rural drainage basins in Maine and northern New Hampshire. 
others, 2011), maximum developed land cover is 3.7 percent (mean of 0.7 percent for all 24 basins). Drainage alterations are assumed to accompany development and are considered negligible for all study basins in this report.

When using the regression equations, the basin characteristics needed for the equations (explanatory variables) should be derived using the same or comparable methods with the same sets of data as those documented in this report. Basin characteristics derived using other techniques or datasets or using values outside the ranges (and combined ranges of multiple explanatory variables in a single equation (fig. 5-8) used to develop these regression equations (table 2) will yield results of unknown error.

\section{Summary}

Regression equations offer a statistical method for estimating streamflows at ungaged locations, which is useful for water management, project planning, and other activities related to monitoring and regulating surface waters. The U.S. Geological Survey and the Maine Department of Transportation used streamflow data to develop dependent variables for 130 regression equations for estimating monthly and annual mean and $1,5,10,25,50,75,90,95$, and 99 percentile streamflows for ungaged, unregulated rivers in Maine and northern New Hampshire along with the data and methods used to derive them in an effort to delineate hydrologic conditions. The regression equations presented in this report supersede previously published regression equations because of the updated streamflow and basin characteristics data used in this report.

Daily streamflow data from 24 streamgages in Maine and northern New Hampshire were used to derive the regression equations. Streamflow in these 24 rural, unregulated basins was deemed to be substantially unaffected by diversions and (or) regulation by dams or reservoirs. The land cover in the study basins was mostly forested; open water and wetlands composed a mean of 8.3 percent of the study basin areas, and developed land of any kind composed less than 10 percent of any study basin area. Given recent studies documenting climatic trends and their effects on hydrology in Maine and New England, streamflow data collected during the 30-year period from October 1, 1982, through September 30, 2012, were used to derive the dependent variables for this report, thereby representing contemporary hydrologic conditions in Maine and northern New Hampshire.

Sixty-eight explanatory variables comprising characteristics such as geology, land cover, land use, precipitation, and temperature were derived using a geographic information system and tested for use as potential explanatory variables for the dependent streamflow variables. Ordinary least squares regression of all possible subsets of 68 explanatory variables for each of 130 dependent streamflow variables were used to select the explanatory variables that would appear in the final regression equations. Emphasis was placed on developing a coherent set of equations in an effort to reduce the possibility of discontinuities in the percentile estimates. Weighted least squares (WLS) regression techniques were used to derive the final coefficients and measures of uncertainty for the regression equations. WLS weights were computed as a function of the number of complete water years of record from water years 1983 to 2012 divided by the mean record length for all of the stations used in the analysis.

Eight basin characteristics serve as the final explanatory variables for estimating monthly and annual mean and $1,5,10,25,50,75,90,95$, and 99 percentile streamflows: drainage area, distance from the coast, mean and maximum basin elevation, mean basin slope, mean basin percentage of hydrologic soil group A (HGA), fraction of sand and gravel aquifers, and percent open water. Drainage area is a highly significant explanatory variable for all percentile streamflows and for all monthly and annual mean streamflows; larger drainage basins contribute greater streamflows. Mean basin elevation and fraction of sand and gravel aquifer are both significant explanatory variables for the annual period and low flow months. Distance from the coast provides explanatory power for the variability in February, March, and April flows. Percent open water, which is a measure of storage, provides explanatory power during spring months, with greater amounts of open water corresponding with lower flows in March and April and higher flows in May and June, in general. Mean basin slope provides explanatory power for streamflows in February, May, and June, with steeper slopes contributing to higher streamflows, in general. Maximum basin elevation provides explanatory power for November, with higher elevations corresponding with higher streamflows. Mean basin percent of HGA (well-drained soils) provides explanatory power for streamflows in December and January, with higher percentages of HGA corresponding with higher streamflows.

The largest uncertainties are associated with regression equations for the lowest streamflows derived for months during which the lowest streamflows of the year occur (such as the 1 and 5 percentiles for August and September). The regression equations have been derived from streamflow and basin characteristics data for unregulated, rural drainage basins without substantial drainage alterations (for example, diversions and (or) regulation by dams or reservoirs, tile drainage, irrigation, channelization, and impervious paved surfaces); therefore, using them for regulated or urbanized basins with substantial drainage alterations will yield results of unknown error. Basin characteristics derived using techniques or datasets other than those documented in this report or using values outside the ranges (and combined ranges of multiple explanatory variables in a single equation) used to develop these regression equations will yield streamflow estimates of unknown error. 


\section{References Cited}

Armstrong, W.H., Collins, M.J., and Snyder, N.P., 2012, Increased frequency of low-magnitude floods in New England: Journal of the American Water Resources Association, v. 48 , no. 2, p. 306-320, http://dx.doi.org/10.1111/ j.1752-1688.2011.00613.x.

Collins, M.J., 2009, Evidence for changing flood risk in New England since the late 20th century: Journal of the American Water Resources Association, v. 45, no. 2, p. 1-12, http://dx.doi.org/10.1111/j.1752-1688.2008.00277.x.

Douglas, E.M., and Fairbank, C.A., 2011, Is precipitation in northern New England becoming more extreme? Statistical analysis of extreme rainfall in Massachusetts, New Hampshire, and Maine and updated estimates of the 100-year storm: Journal of Hydrologic Engineering, v. 16, no. 3, p. 203-217, http://dx.doi.org/10.1061/(ASCE)HE.19435584.0000303.

Dudley, R.W., 2004, Estimating monthly, annual, and low 7-day, 10-year streamflows for ungaged rivers in Maine: U.S. Geological Survey Scientific Investigations Report 2004-5026, 22 p. [Also available at http://pubs.usgs.gov/ sir/2004/5026/.]

Dudley, R.W., and Hodgkins, G.A., 2002, Trends in streamflow, river ice, and snowpack for coastal river basins in Maine during the 20th century: U.S. Geological Survey Water-Resources Investigations Report 02-4245, 26 p. [Also available at http://me.water.usgs.gov/reports/ wrir02-4245.pdf.]

Dunne, Thomas, and Leopold, L.B., 1978, Water in environmental planning: San Francisco, Calif., Freeman and Co., $818 \mathrm{p}$.

Falcone, J.A., 2011, GAGES-II-Geospatial attributes of gages for evaluating streamflow: U.S. Geological Survey metadata, accessed August 25, 2015, at http://water.usgs.gov/GIS/metadata/usgswrd/XML/ gagesII_Sept2011.xml.

Falcone, J.A., Carlisle, D.M., Wolock, D.M., and Meador, M.R., 2010, GAGES-A stream gage database for evaluating natural and altered flow conditions in the conterminous United States: Ecology, v. 91, no. 2, p. 621, accessed August 25, 2015, at http://esapubs.org/Archive/ecol/E091/045/ metadata.htm.

Fry, J.A., Xian, George, Jin, Suming, Dewitz, J.A., Homer, C.G., Yang, Limin, Barnes, C.A., Herold, N.D., and Wickham, J.D., 2011, Completion of the 2006 national land cover database for the conterminous United States: Photogrammetric Engineering and Remote Sensing, v. 77, no. 9, p. 858-864, http://www.mrlc.gov/downloadfile2. php?file=September2011PERS.pdf.
Gesch, Dean, Evans, Gayla, Mauck, James, Hutchinson, John, and Carswell, W.J., Jr., 2009, The national map-Elevation: U.S. Geological Survey Fact Sheet 2009-3053, 4 p. [Also available at http://pubs.usgs.gov/fs/2009/3053/.]

Helsel, D.R., and Hirsch, R.M., 2002, Statistical methods in water resources: U.S. Geological Survey Techniques of Water-Resources Investigations, book 4, chap. A3, $522 \mathrm{p}$. [Also available at http://pubs.usgs.gov/twri/twri4a3/.]

Hodgkins, G.A., 1999, Estimating the magnitude of peak flows for streams in Maine for selected recurrence intervals: U.S. Geological Survey Water-Resources Investigations Report 99-4008, 45 p. [Also available at http://me.water.usgs.gov/reports/99-4008.pdf.]

Hodgkins, G.A., 2010, Historical changes in annual peak flows in Maine and implications for flood-frequency analyses: U.S. Geological Survey Scientific Investigations Report 2010-5094, 38 p. [Also available at http://pubs.usgs.gov/ $\operatorname{sir} / 2010 / 5094 /$.

Hodgkins, G.A., 2013, The importance of record length in estimating the magnitude of climatic changes: an example using 175 years of lake ice-out dates in New England: Climatic Change, v. 119, no. 3, p. 705-718, http://dx.doi.org/10.1007/s10584-013-0766-8.

Hodgkins, G.A., and Dudley, R.W., 2005, Changes in the magnitude of annual and monthly streamflows in New England, 1902-2002: U.S. Geological Survey Scientific Investigations Report 2005-5135, 37 p. [Also available at http://pubs.usgs.gov/sir/2005/5135/.]

Hodgkins, G.A., and Dudley, R.W., 2006a, Changes in latewinter snowpack depth, water equivalent, and density in Maine, 1926-2004: Hydrological Processes, v. 20, no. 4, p. 741-751, http://dx.doi.org/10.1002/hyp.6111.

Hodgkins, G.A., and Dudley, R.W., 2006b, Changes in the timing of winter-spring streamflows in eastern North America, 1913-2002: Geophysical Research Letters, v. 33, L06402, 5 p., http://dx.doi.org/10.1029/2005GL025593.

Hodgkins, G.A., and Dudley, R.W., 2011, Historical summer base flow and stormflow trends for New England rivers: Water Resources Research, v. 47, W07528, 16 p., http://dx.doi.org/10.1029/2010WR009109.

Hodgkins, G.A., Dudley, R.W., and Huntington, T.G., 2003, Changes in the timing of high river flows in New England over the 20th century: Journal of Hydrology, v. 278, nos. 1-4, p. 244-252, http://dx.doi.org/10.1016/S00221694(03)00155-0. 
Huntington, T.G., Hodgkins, G.A., Keim, B.D., and Dudley, R.W., 2004, Changes in the proportion of precipitation occurring as snow in New England (1949-2000): Journal of Climate, v. 17, no. 13, p. 2626-2636, http://dx.doi.org/10.1175/1520-0442(2004)017<2626:CITP $\mathrm{OP}>2.0 . \mathrm{CO} ; 2$.

Irland, L.C., 1998, Maine's forest area, 1600-1995-Review of available estimates: Maine Agricultural and Forest Experiment Station Miscellaneous Publication 736, 12 p. [Also available at http://digitalcommons.library.umaine.edu/ cgi/viewcontent.cgi?article=1033\&context=aes_miscpubs.]

Karl, T.R., and Knight, R.W., 1998, Secular trends of precipitation amount, frequency, and intensity in the United States: Bulletin of the American Meteorological Society, v. 79, no. 2, p. 231-241. [Also available at http://dx.doi.org/10.1175/1520-0477(1998)079<0231:STOP $\mathrm{AF}>2.0 . \mathrm{CO} ; 2$.

Lombard, P.J., 2004, August median streamflow on ungaged streams in eastern coastal Maine: U.S. Geological Survey Scientific Investigations Report 2004-5157, 15 p., http://pubs.usgs.gov/sir/2004/5157/.

Lombard, P.J., 2010, June and August median streamflows estimated for ungaged streams in southern Maine: U.S. Geological Survey Scientific Investigations Report 20105179, 16 p., http://pubs.usgs.gov/sir/2010/5179/.

Lombard, P.J., Tasker, G.D., and Nielsen, M.G., 2003, August median streamflow on ungaged streams in eastern Aroostook County, Maine: U.S. Geological Survey Water-Resources Investigations Report 03-4225, 20 p., http://pubs.usgs.gov/wri/wri034225/.

Maine Office of GIS, 2015, Aquifer polygons: Maine Office of GIS digital data, accessed August 24, 2015, at http://www.maine.gov/dacf/mgs/pubs/digital/aquifers.htm.

Multi-Resolution Land Characteristics Consortium, 2014, National land cover database 2006: Multi-Resolution Land Characteristics Consortium digital data, accessed August 25, 2015, at http://www.mrlc.gov/nlcd06_data.php.

National Climatic Data Center, 2015, Climate data online, accessed August 25, 2015, at https://gis.ncdc.noaa.gov/map/ viewer $/ \#$ app $=$ cdo\&cfg $=$ cdo\& theme $=$ normals \&layers $=01 \& \mathrm{e}$ xtent $=-71: 42.5:-66: 49$.
New Hampshire Geographically Referenced Analysis and Information Transfer, 2015, Aquifers-Aquifer boundaries, in Layers by data category: New Hampshire Geographically Referenced Analysis and Information Transfer digital data, accessed August 25, 2015, at ftp://ftp.granit.sr.unh.edu/pub/ GRANIT_Data/Vector_Data/Inland_Water_Resources/daquifer/d-aquiferboundaries.

Parker, G.W., 1977, Methods for determining selected flow characteristics for streams in Maine: U.S. Geological Survey Open-File Report 78-871, 31 p. [Also available at http://pubs.er.usgs.gov/publication/ofr78871.]

Rantz, S.E., and others, 1982, Measurement and computation of streamflow: U.S. Geological Survey Water-Supply Paper 2175, 2 v., 631 p. [Also available at http://pubs.usgs.gov/ wsp/wsp2175/.]

U.S. Census Bureau, 2012, Maine 2010-Summary population and housing characteristics, in 2010 census of population and housing: U.S. Census Bureau CPH-1-21, 193 p. plus maps. [Also available at https:/www.census.gov/prod/ cen2010/cph-1-21.pdf.]

U.S. Department of Agriculture, 1986, Urban hydrology for small watersheds: U.S. Department of Agriculture Technical Release 55, 164 p. [Also available at http://www.hydrocad.net/tr-55.htm.]

U.S. Department of Agriculture, 1994, State soil geographic data base (STATSGO)_Data users guide: U.S. Department of Agriculture Miscellaneous Publication 1492, 113 p.

U.S. Geological Survey, 2001, Elevations and distances in the United States: U.S. Geological Survey Web page, accessed November 26, 2014, at http://pubs.er.usgs.gov/ publication/70048223.

U.S. Geological Survey, 2014a, National elevation dataset: U.S. Geological Survey database, accessed November 26, 2014, at http://ned.usgs.gov/.

U.S. Geological Survey, 2014b, USGS annual water data reports: U.S. Geological Survey Web page, accessed December 10, 2014, at http://wdr.water.usgs.gov/.

U.S. Geological Survey, 2014c, USGS water data for the nation: U.S. Geological Survey National Water Information System Web interface, accessed December 8, 2014, at http://waterdata.usgs.gov/nwis/.

Wolock, D.M., 1997, STATSGO soil characteristics for the conterminous United States: U.S. Geological Survey OpenFile Report 97-656 metadata, accessed August 25, 2015, at http://water.usgs.gov/lookup/getspatial?muid. 


\section{Appendix 1. Monthly and Annual Mean and Selected Percentile Streamflows for Selected U.S. Geological Survey Streamgages in Maine and Northern New Hampshire}

Tables 1-1-1-10. Computed monthly and annual streamflow statistics for selected

U.S. Geological Survey streamgages in Maine and northern New Hampshire

$$
\begin{array}{cl}
1-1 . & \text { Mean } \\
1-2 . & 1 \text { percentile } \\
1-3 . & 5 \text { percentile } \\
1-4 . & 10 \text { percentile } \\
1-5 . & 25 \text { percentile } \\
1-6 . & 50 \text { percentile } \\
1-7 . & 75 \text { percentile } \\
1-8 . & 90 \text { percentile } \\
1-9 . & 95 \text { percentile } \\
1-10 . & 99 \text { percentile }
\end{array}
$$




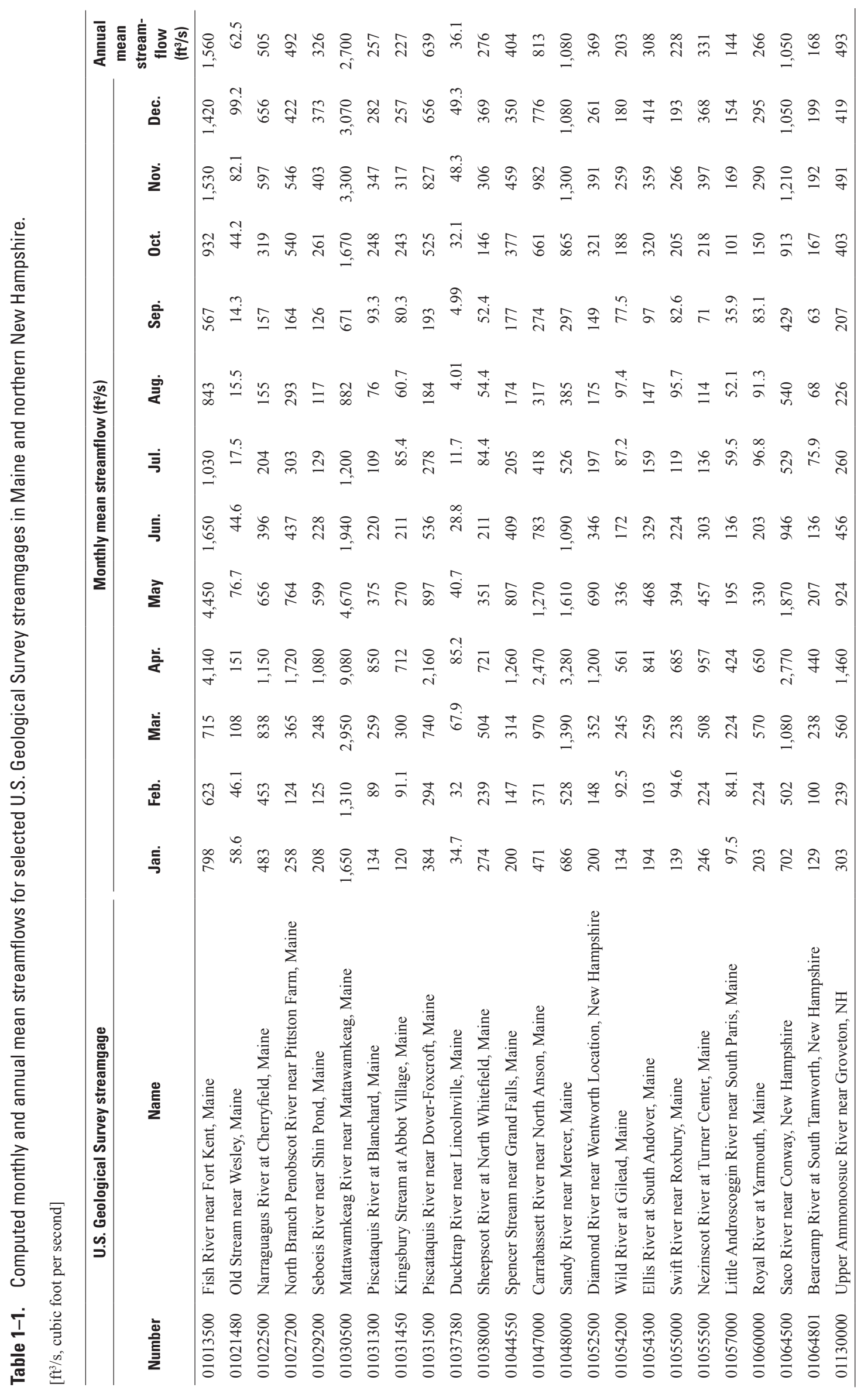




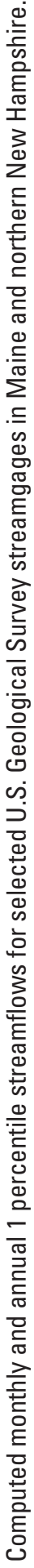

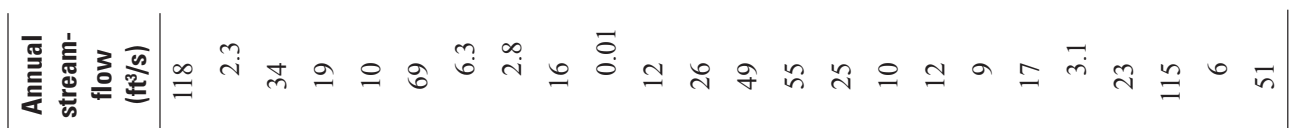
迎

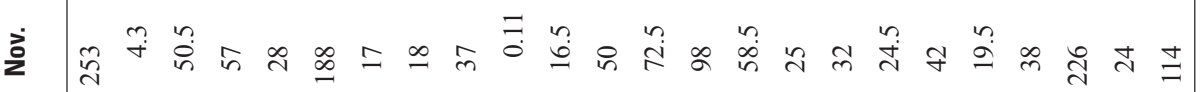
வ்

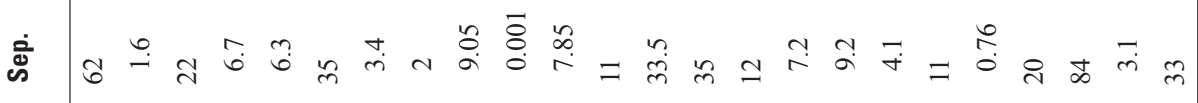
岛

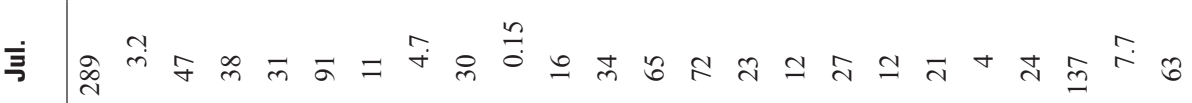
馬 एँ

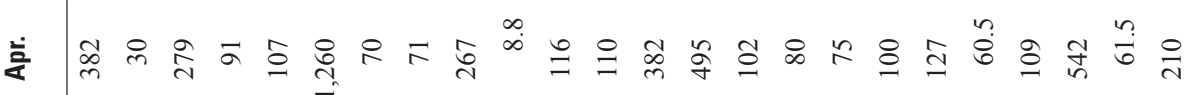

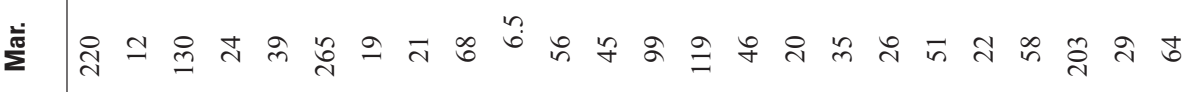
迎 ஊ

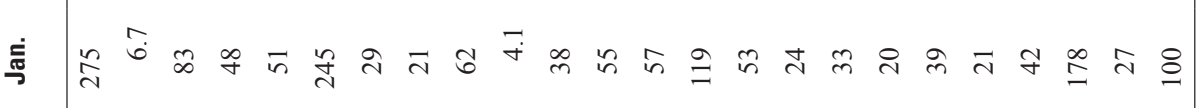

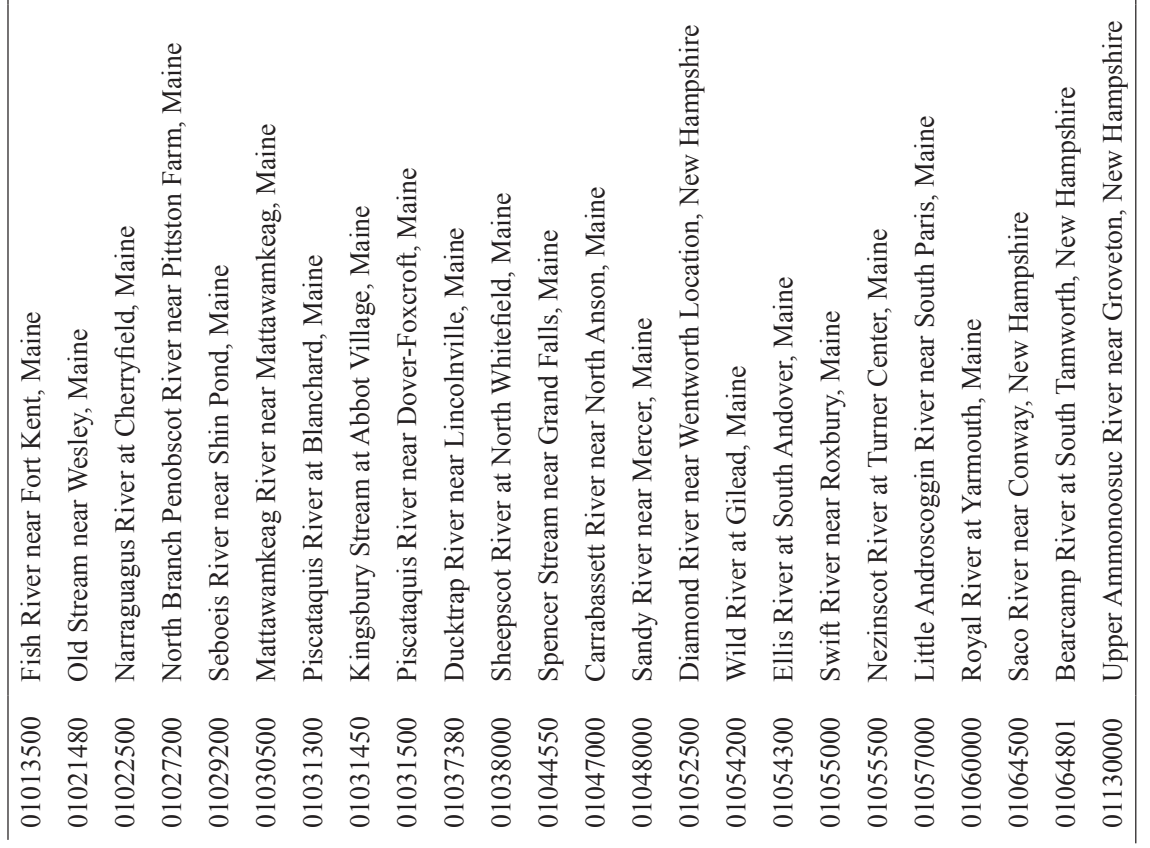


|

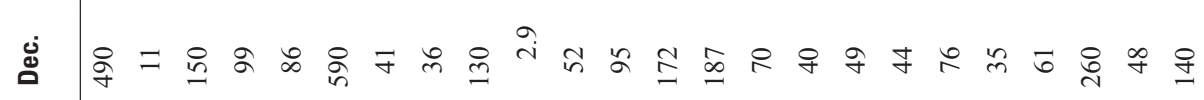
ż

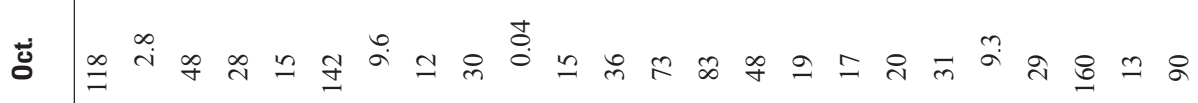
mं

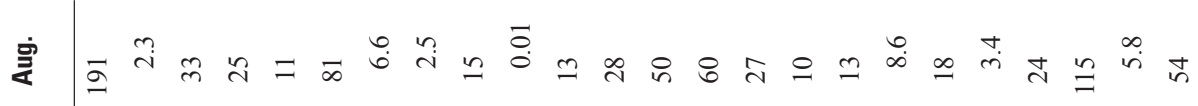

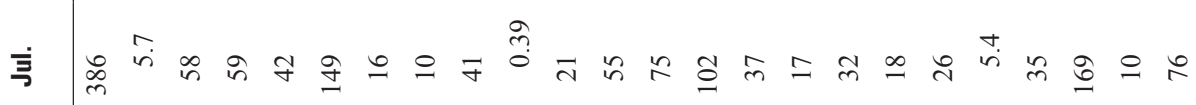
馬

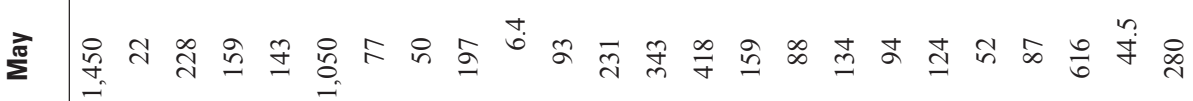

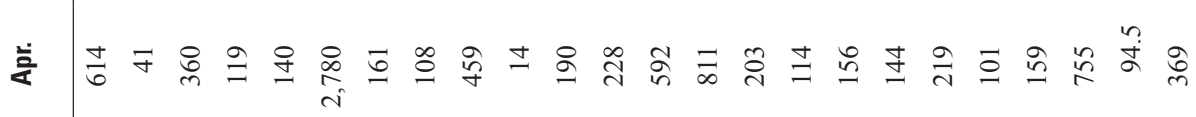

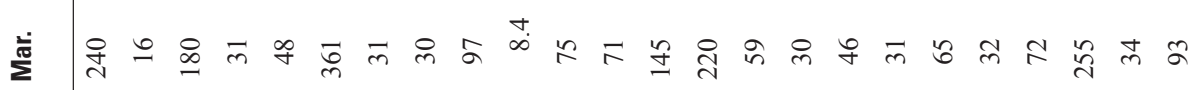

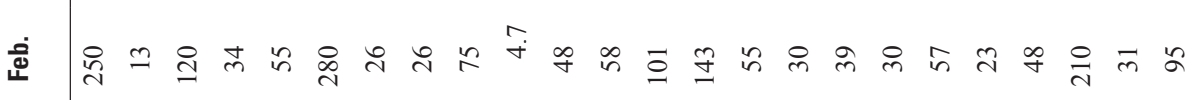
臭

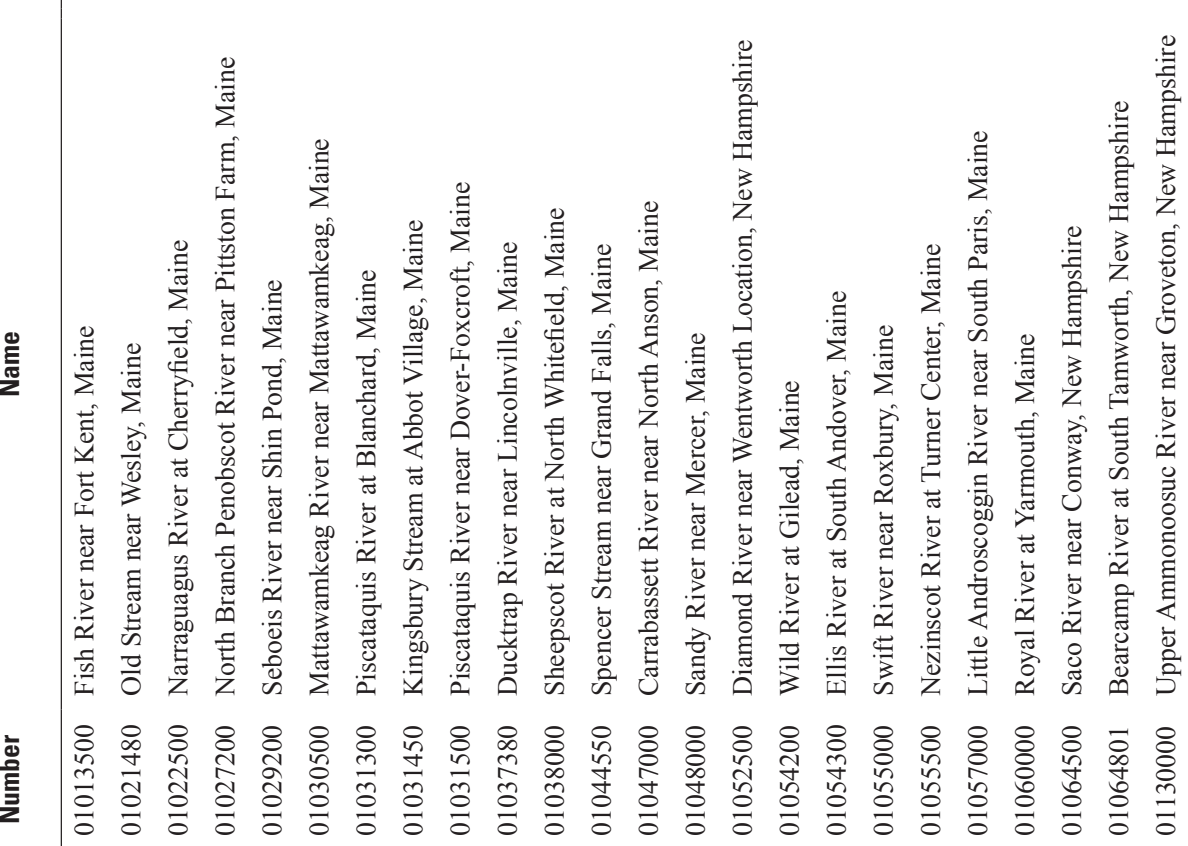




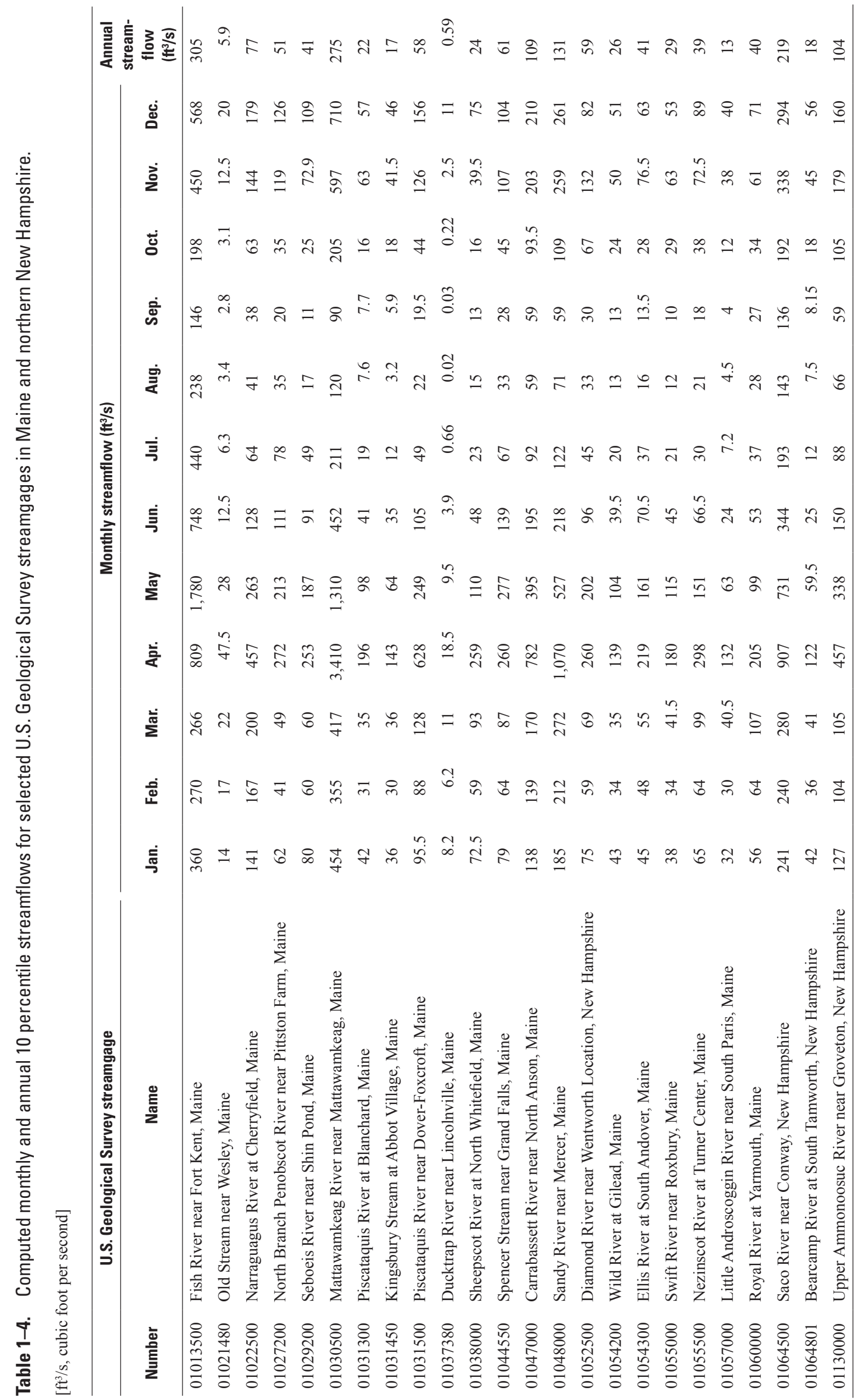




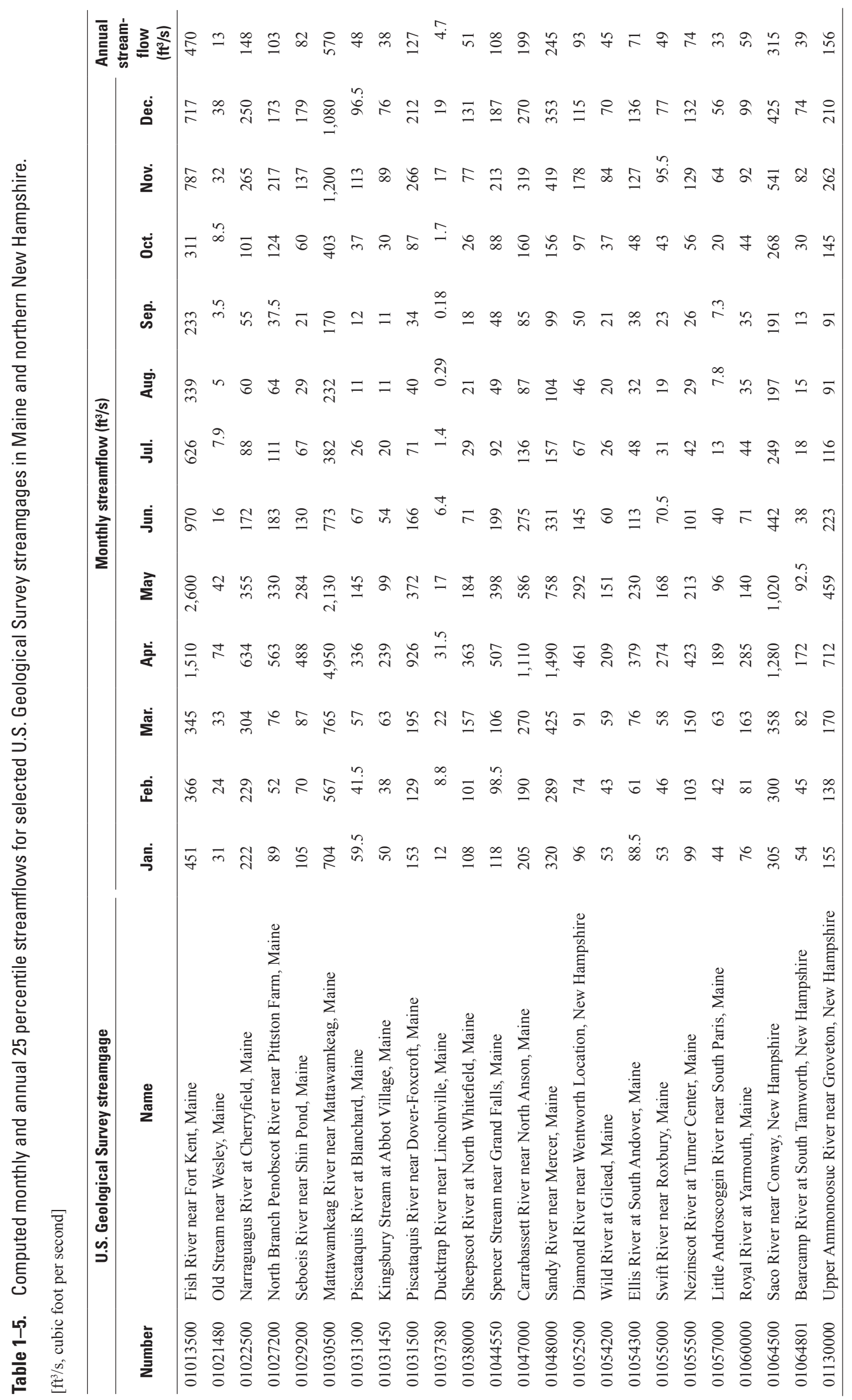




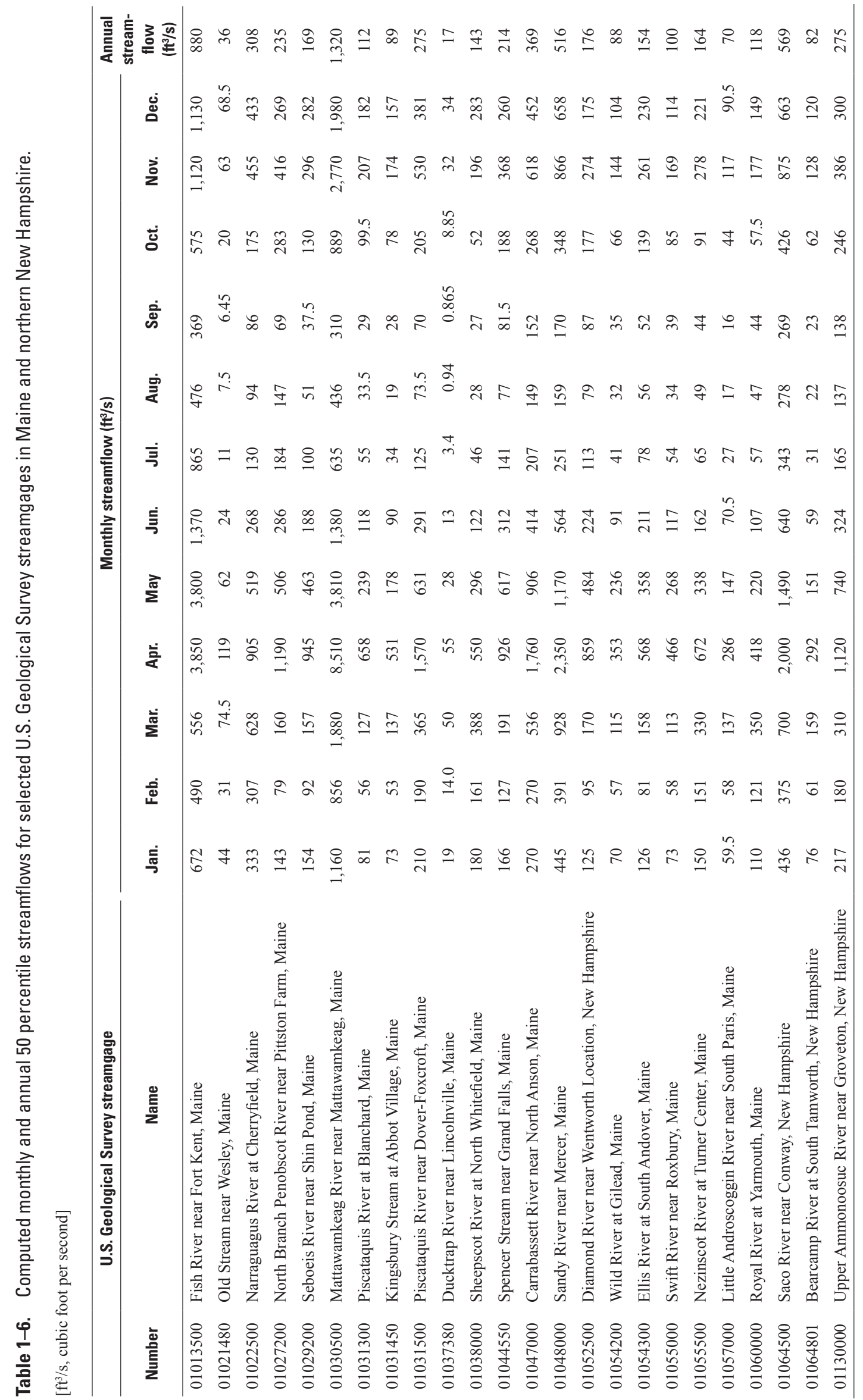




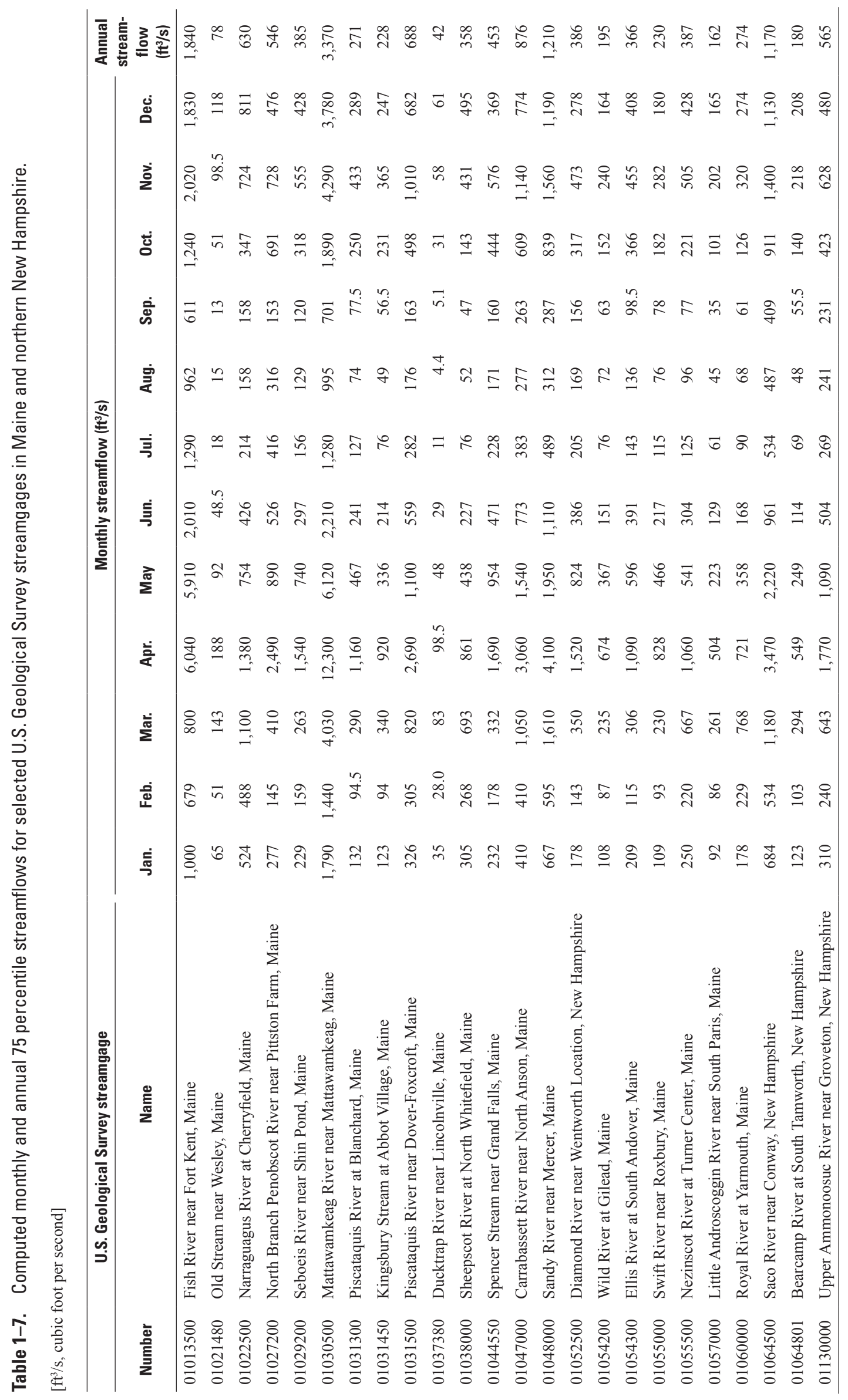




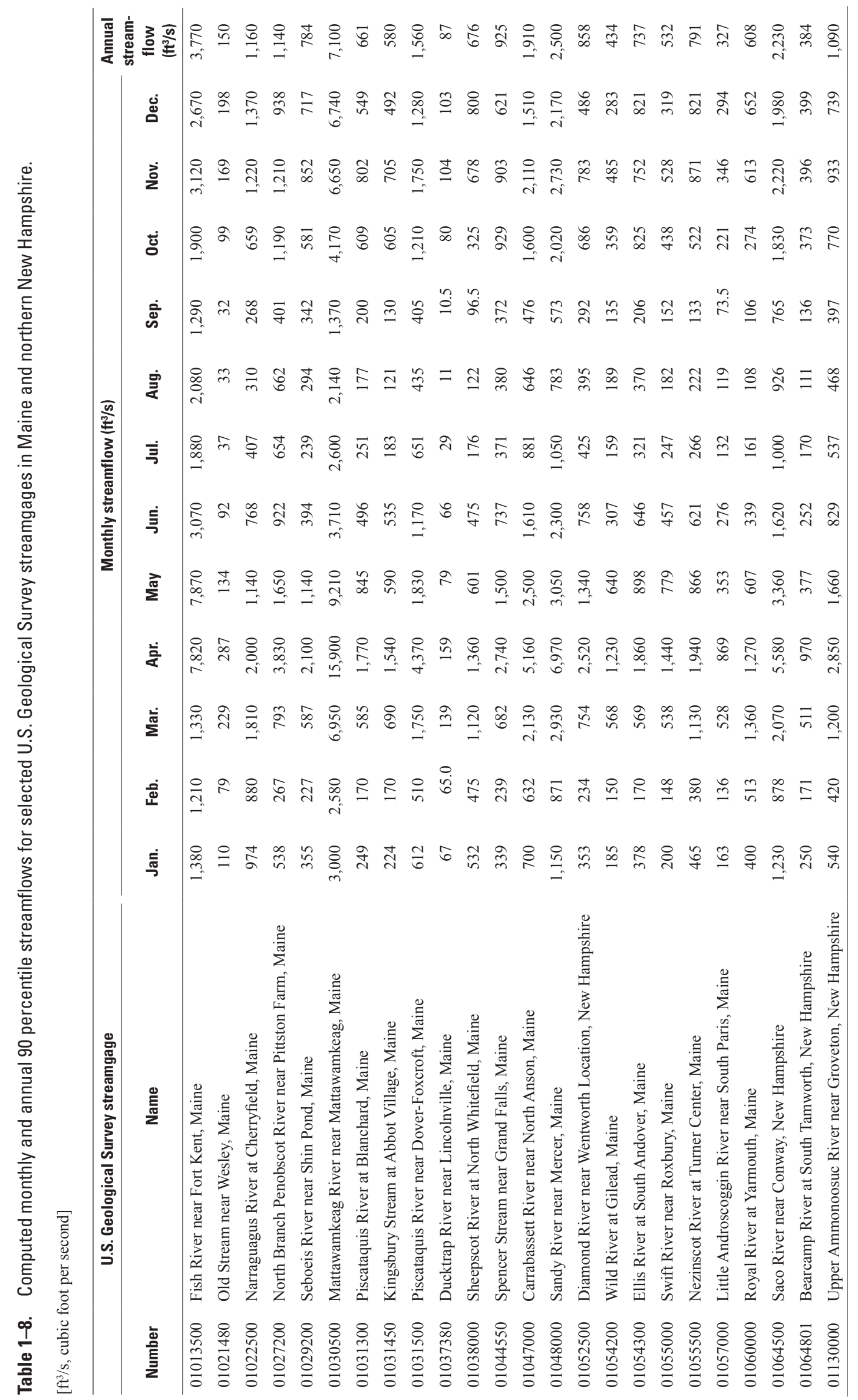




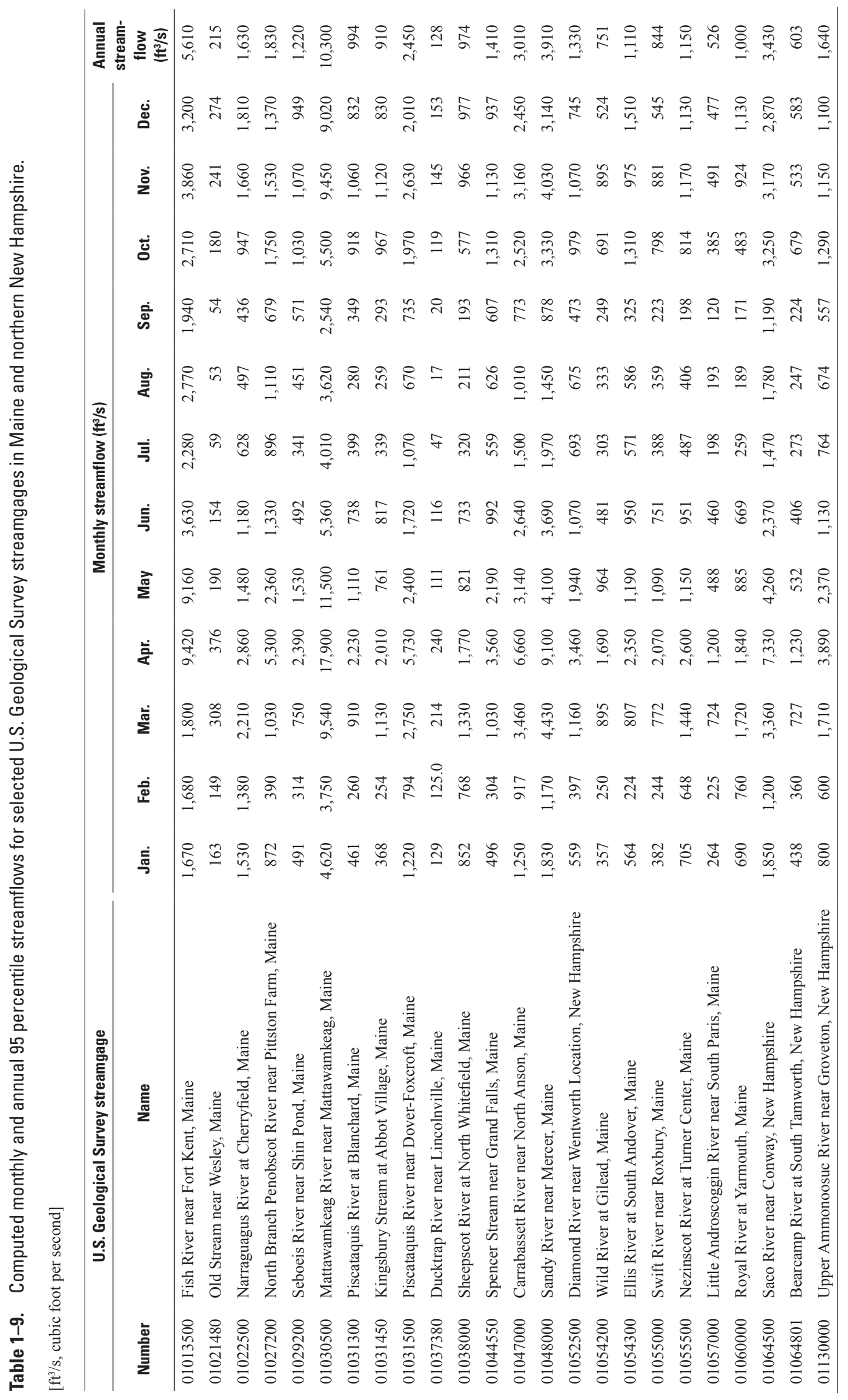




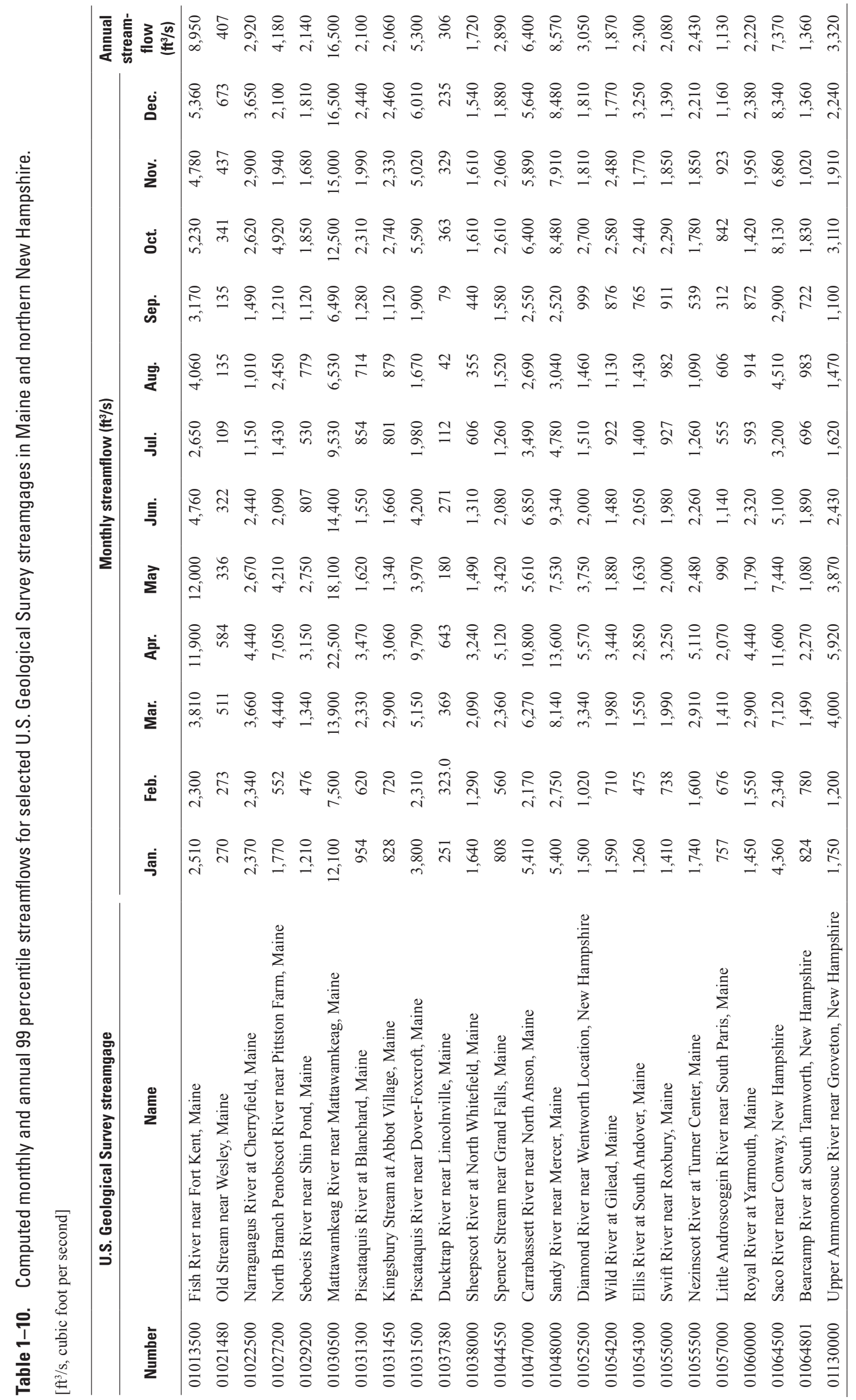



For more information concerning this report, contact: Director, New England Water Science Center U.S. Geological Survey 196 Whitten Road

Augusta, ME 04330

dc_nweng@usgs.gov or visit our Web site at: http://newengland.water.usgs.gov

Publishing support by:

The Pembroke Publishing Service Center. 


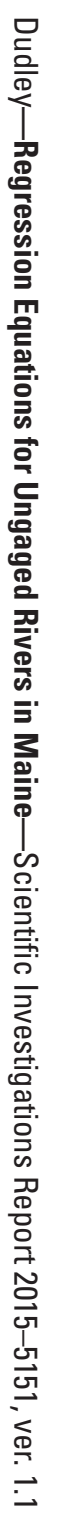

